\title{
Oligomerization of GPCRs involved in endocrine regulation
}

\author{
Gunnar Kleinau, Anne Müller and Heike Biebermann \\ Institute of Experimental Pediatric Endocrinology (IEPE), Charité-Universitätsmedizin, Berlin, Germany
}

Correspondence

should be addressed

to $\mathrm{H}$ Biebermann

Email

heike.biebermann@charite.de

\begin{abstract}
More than 800 different human membrane-spanning G-protein-coupled receptors (GPCRs) serve as signal transducers at biological barriers. These receptors are activated by a wide variety of ligands such as peptides, ions and hormones, and are able to activate a diverse set of intracellular signaling pathways. GPCRs are of central importance in endocrine regulation, which underpins the significance of comprehensively studying these receptors and interrelated systems. During the last decade, the capacity for multimerization of GPCRs was found to be a common and functionally relevant property. The interaction between GPCR monomers results in higher order complexes such as homomers (identical receptor subtype) or heteromers (different receptor subtypes), which may be present in a specific and dynamic monomer/oligomer equilibrium. It is widely accepted that the oligomerization of GPCRs is a mechanism for determining the fine-tuning and expansion of cellular processes by modification of ligand action, expression levels, and related signaling outcome. Accordingly, oligomerization provides exciting opportunities to optimize pharmacological treatment with respect to receptor target and tissue selectivity or for the development of diagnostic tools. On the other hand, GPCR heteromerization may be a potential reason for the undesired side effects of pharmacological interventions, faced with numerous and common mutual signaling modifications in heteromeric constellations. Finally, detailed deciphering of the physiological occurrence and relevance of specific GPCR/GPCR-ligand interactions poses a future challenge. This review will tackle the aspects of GPCR oligomerization with specific emphasis on family A GPCRs involved in endocrine regulation, whereby only a subset of these receptors will be discussed in detail.
\end{abstract}

\section{Key Words}

- G-protein-coupled receptors

- homomers

- heteromers

- homooligomerization

- heterooligomerization

- dimers

oligomers

- endocrine regulation

- endocrine diseases

- signaling
Journal of Molecular Endocrinology (2016) 57, R59-R80

\section{G-protein-coupled receptors}

The importance of GPCRs

Physiological functions such as development, growth, behavior, learning, emotions, senses and aging are strongly dependent on the control of endocrine circuits. Hormonal signals exert their action via binding to nuclear receptors or membrane-bound receptors. The largest superfamily of membrane-bound receptors are G-protein-coupled receptors (GPCRs) (Kristiansen 2004), which are involved in the modulation of almost all physiological processes (Limbird 2004). The relevance of GPCRs is due to their fundamental role as information transducers (Raymond 1995, Wess 1998) by serving as hubs for signals transiting biological barriers (Rosenbaum et al. 2009).

Activation of GPCRs by different ligands, crosstalk of receptors within the membrane, and their interaction

Published by Bioscientifica Ltd 
with cellular or extracellular proteins determine the subsequently induced intracellular signaling pathway. The overall result of GPCR activation are specific physiological responses (Schwartz et al. 2006) and are based on various mechanisms such as induction of gene expression (Ho et al. 2009) or ion channel regulation (Veldhuis et al.2015). Due to their key role in tuning physiological processes, approximately $50 \%$ of approved drugs modulate GPCRs (Hopkins \& Groom 2002, Tyndall \& Sandilya 2005, Schlyer \& Horuk 2006, Mason et al. 2012).

\section{How do GPCRs function?}

GPCRs are activated by a wide variety of ligands including small peptides, nucleotides, ions, amines, or even large glycoprotein hormones, and they activate various signaling pathways (Kristiansen 2004). Based on different conserved amino acid motifs, the superfamily of GPCRs is subdivided into several families, whereby family $\mathrm{A}$, also known as family 1 or rhodopsin-like GPCRs, constitute the family with most different members (Fredriksson et al. 2003, Fredriksson \& Schioth 2005). They share a common structural architecture of seven transmembrane helices (TMHs) that are connected by three intracellular loops (ICLs) and three extracellular loops (ECLs). This architecture is confirmed by the inspection of solved GPCR structures (reviewed in Kobilka \& Schertler 2008, Hanson \& Stevens 2009, Lodowski et al. 2009). As a result of advanced experimental methods (Tate \& Schertler 2009), many GPCR crystal structures have been published in the last decade (Zhao \& Wu 2012, Piscitelli et al. 2015) and are useful tools to improve pharmacological approaches directed to GPCRs (Carlsson et al. 2011, Kontoyianni \& Liu 2012, Mason et al. 2012, Shoichet \& Kobilka 2012).

Most of the endogenous and synthetic ligands of family A GPCRs are believed to bind within the transmembrane domain close to the second extracellular loop 2 (ECL2) (Surgand et al. 2006, Wichard et al.2011), with the exception of glycoprotein hormone receptors (GPHRs) and leucinerich repeat-containing G-protein-coupled receptors (LGRs) (Svendsen et al. 2008, Kleinau \& Krause 2009, Svendsen et al. 2009, Kleinau et al. 2013). Based on a large amount of experimental data, a 'global toggle switching' mechanism is suggested to occur during ligand-induced activation (Schwartz et al. 2006, Smit et al. 2007). Correspondingly, activation is characterized by a spatial rearrangement of the TMHs relative to one another (Scheerer et al. 2008, 2009, Schertler 2008). This structural rearrangement is supported by amino acids acting as 'micro-switches' (Ahuja \& Smith 2009, Hofmann et al. 2009, Nygaard et al. 2009).
Different GPCR conformations are assumed to be related to different signaling activity states (Seifert \& Wenzel-Seifert 2002, Kobilka \& Deupi 2007, Deupi \& Standfuss 2011). Due to the capability for activation of G-proteins and several G-protein-independent signaling pathways (e.g. via arrestin), GPCRs share common 'read-outs', even if they bind different ligands (reviewed in Galandrin et al. 2007, Oldham \& Hamm 2008).

\section{GPCR oligomerization as a regulatory mechanism in signaling}

\section{How can an oligomeric GPCR constellation be defined, and is there a relevance for oligomerization?}

Organisation of GPCRs as oligomers is an interesting feature under structural and functional prospective. It has been reported for numerous GPCRs (Tadagaki et al. 2012a), also in native tissue (Albizu et al. 2010a, Bouvier 2001, Rozenfeld \& Devi 2011). Dimerization is a general term used to describe a GPCR-x/GPCR-x (homomer) or GPCR-x/GPCR-y (heteromer) constellation. The term oligomerization is used for dimeric, tetrameric or higher order complexes between GPCR protomers (Fig. 1). Such GPCR-GPCR interrelations should be characterized by the following parameters (for further details, see also (Gomes et al. 2016)): (1) physical interactions (side-chain interactions); (2) direct mutual functional modulation; or (3) a particular spatial distance to one another. It could be hypothesized that a relevant oligomerization is dependent on a functional significance (Tadagaki et al. 2012a). In case of heterodimerization, GPCR expression in the same cell type (Waldhoer et al. 2005, Pin et al. 2007) and simultaneous occurrence (Gonzalez et al. 2012) are prerequisites. Oligomerization has been reported for several GPCR subfamilies such as for the family A, family B or taste receptors (Li et al. 2002, Harikumar et al. 2008, Ng et al. 2012, Ng \& Chow 2015).

Which general functional role may GPCR oligomerization have in physiology? To date, the functional significance of both homo- and heteromerization on the molecular level is related to the determination, enlargement and fine-tuning of signaling options such as signal amplification or modification (see below for details). Moreover, the GPCR capacity to form heteromers particularly provides an opportunity for their respective ligands to act in a synchronized manner and thereby to balance or coordinate related cellular responses and biological processes (such as metabolism or reproduction). As a hypothetical example, one ligand activates a specific

Published by Bioscientifica Ltd 
A (or Protomer)

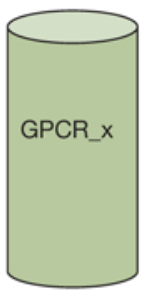

E

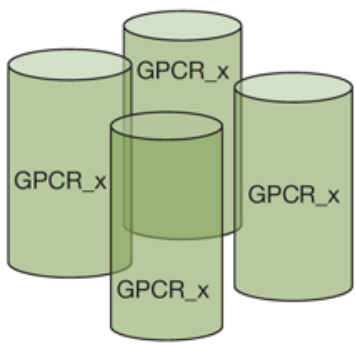

B

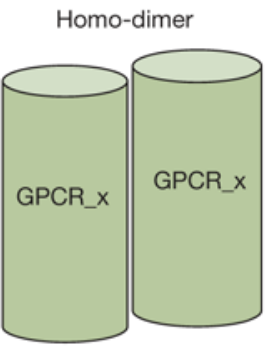

C

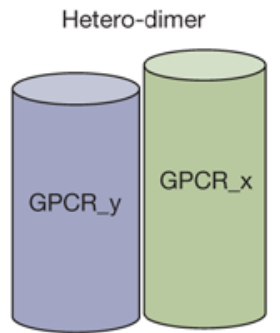

D

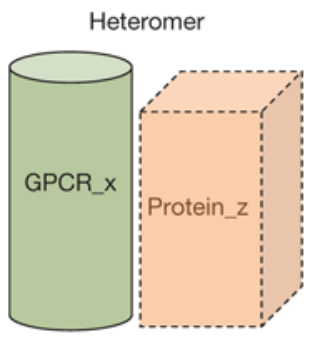

\section{Figure 1}

Putative constellations of oligomers. (A) A particular GPCR (GPCR x) as a monomer (schematic cylinder indicates the entire receptor). (B) Two monomers of the same GPCR interacting as a homodimer. (C) Dimerization between GPCR_x with a different GPCR_y. (D) GPCR_x may potentially interact with a non-GPCR. (E) GPCR_x may also form homooligomers with different interfaces between the protomers. (F) Assuming tetrameric (or higher order) GPCR oligomers, complexes with different protomer ratios may be formed by GPCR_x and GPCR_y.

receptor, whereas the activity of the interacting heteromeric GPCR is simultaneously inhibited or downregulated by mutual effects, which is an effective and rapid system of counter-regulation. Notably, several GPCRs can interact with other GPCRs as oligomers, also in dependency on diverse cell types that also broadens the spectrum of a specific ligand to direct signaling in different associations with related physiological mechanisms. This general picture (explained in further detail below) becomes more complex in consideration of the frequently observed ligand property to interact with a multitude of diverse GPCR targets such as trace amines (Kleinau et al. 2011, Dinter et al. 2015a).

The involvement of GPCR oligomerization in the regulation of physiological processes, either as homo- or in heterooligomeric constellations, is strongly supported by previous and recent findings, e.g. for the $\alpha 1$-adrenergic receptor $(\alpha 1 \mathrm{AR})$, whereby heterodimerization of $\alpha 1 \mathrm{AR}$ with the chemokine receptor 4 controls blood pressure regulation (Tripathi et al. 2015). Moreover, the trace amineassociated receptor 1 (TAAR1) interacts, for example, with the dopamine-2 receptor (D2R) and, in turn, modifies dopaminergic neurotransmission (Harmeier et al. 2015). Further examples include circadian-controlled heterodimers between the D4R and the $\beta 1$ - or $\alpha 1 \mathrm{~B}$-adrenergic receptor, respectively, that are involved in the regulation of serotonin and melatonin syntheses (Gonzalez et al. 2012) and the interactome of melatonin receptors involved in circadian rhythm regulation (Benleulmi-Chaachoua et al. 2016).

\section{What do we know about interactions between GPCR protomers constituting oligomeric interfaces?}

Several GPCR-GPCR protomer interfaces have been reported under involvement of TMH4 (Carrillo et al. 2004, Hernanz-Falcon et al. 2004, Guo et al. 2005, 2008, Mancia et al. 2008), TMH1, and TMH5-6 (Hebert et al. 1996, McMillin et al. 2011, Yanagawa et al. 2011) or the extracellular N-terminal region (Uddin et al. 2012). The intermolecular interactions are constituted between single amino acids or between multitudes of side chains. Specific roles for such interactions or spatial distances between protomers are not defined as obligate for 'protomer interrelations' or cannot be determined as a standard, and may vary for different GPCRs. In conclusion, different putative interfaces and types of interactions for homoand heterodimers can be assumed, whereby no universal interface property can be suggested. Several interfaces revealed by biophysical or biochemical methods have

Published by Bioscientifica Ltd 


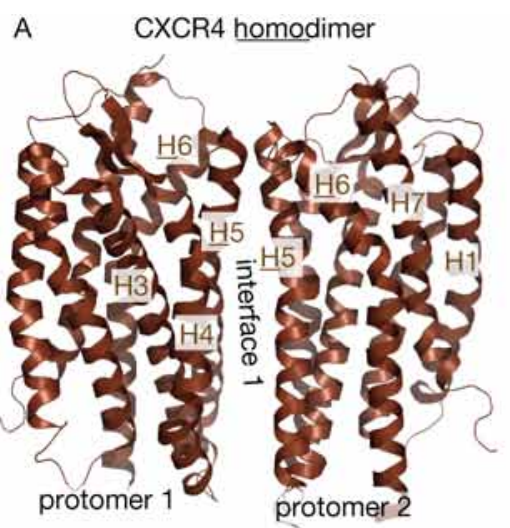

D

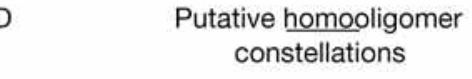

i)

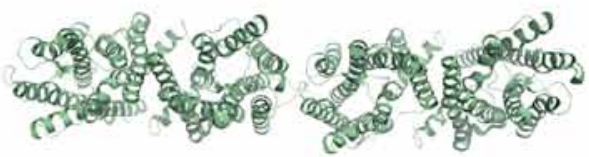

interfaces 1 and 2

ii)

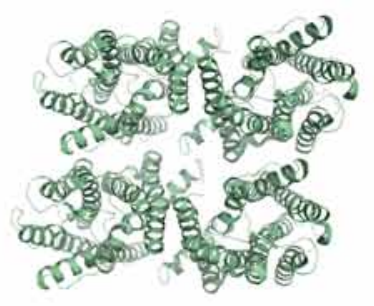

B

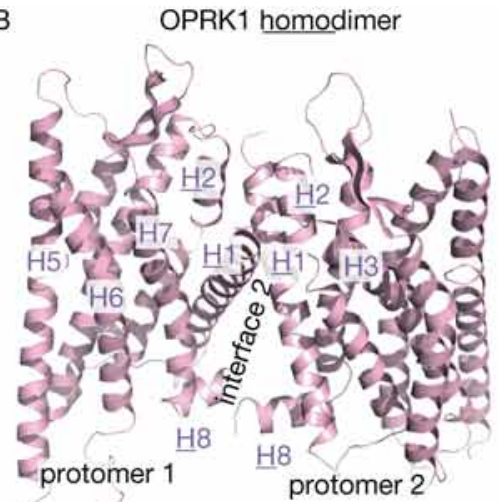

C

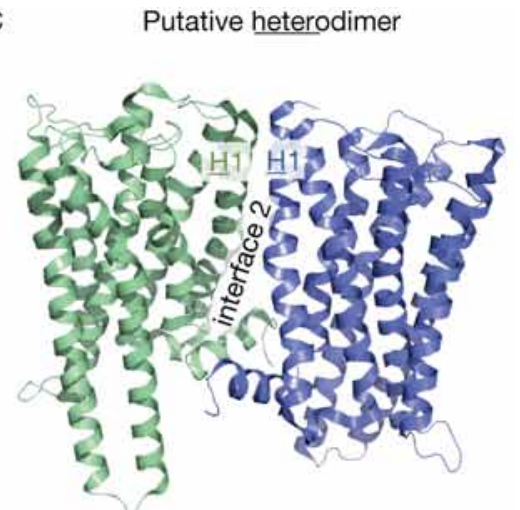

Putative heterooligomer constellations

iii)

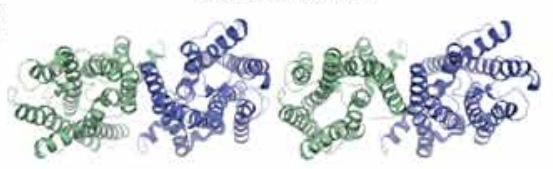

iv)

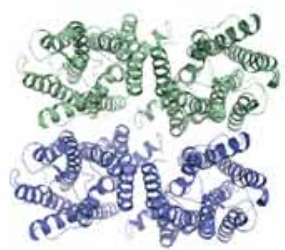

v)

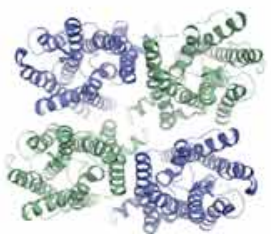

Figure 2

Observed GPCR homodimer interfaces and putative heterodimer constellations. Direct GPCR protomer interfaces are assumed to be characterized at the structural level by specific side-chain interactions or close spatial distances. Interfaces between the protomers have been found under experimental conditions for different GPCRs at the region from ICL2-TMH4 (Bakker et al. 2004, Guo et al. 2005, Mancia et al. 2008), TMH5-TMH6 (George et al. 1998, Yanagawa et al. 2011, Hu et al. 2013), and TMH4-TMH5 (Gorinski et al. 2012). Furthermore, several crystal structures of dimeric GPCR complexes were previously determined, such as those from the (A) chemokine receptor CXCR4 (Wu et al. 2010) or (B) the k-opioid receptor (OPRK1 or KOR (Wu et al. 2012)). For OPRK1, as also for determined $\beta-1$ AR and opsin structures, the protomer interface is located at TMH1-TMH2 and helix 8 (B), respectively. In line with biophysical data, dimer interfaces can be also observed between TMH5-6 (as in A). As a result, heteromeric states should also be characterized by these interfaces, but between diverse protomers (C) (protomers are colored differently for visual separation). For homomers, various scenarios of spatial protomer arrangements (a combination of dimers) can be speculated ( $\mathrm{D}$ i and ii). The identical variety of combinations may also be assumed for heteromers, which finally includes heteromers of homomers (Ferre 2015) (D iii and v). The software PyMOL (Molecular Graphics System, Version 1.3 Schrödinger, LLC) was used for structural representation.

been confirmed by determined crystal structures of GPCR dimers (Fig. 2). Furthermore, the GPCR-GPCR interfaces are most likely to be of dynamic character (Hu et al. 2013). GPCRs were described to be potentially expressed as a mixture of monomers and homomers, and the two forms were found to interconvert dynamically in an equilibrium ((Hern et al. 2010, Kasai et al. 2011, Calebiro et al. 2013, Teichmann et al. 2014), reviewed in Lambert 2010).
○ 2016 Society for Endocrinology Printed in Great Britain

\section{Which functions or molecular properties of GPCRs are influenced by oligomerization?}

Homo- and heterooligomerization is not a prerequisite for a general signaling capacity at family A GPCRs (Whorton et al. 2007), but it defines and widens the spectrum of fine-tuning options in signaling (White et al. 2007, Ciruela et al. 2010, Smith \& Milligan 2010). Oligomerization can have a major influence on the

Published by Bioscientifica Ltd 

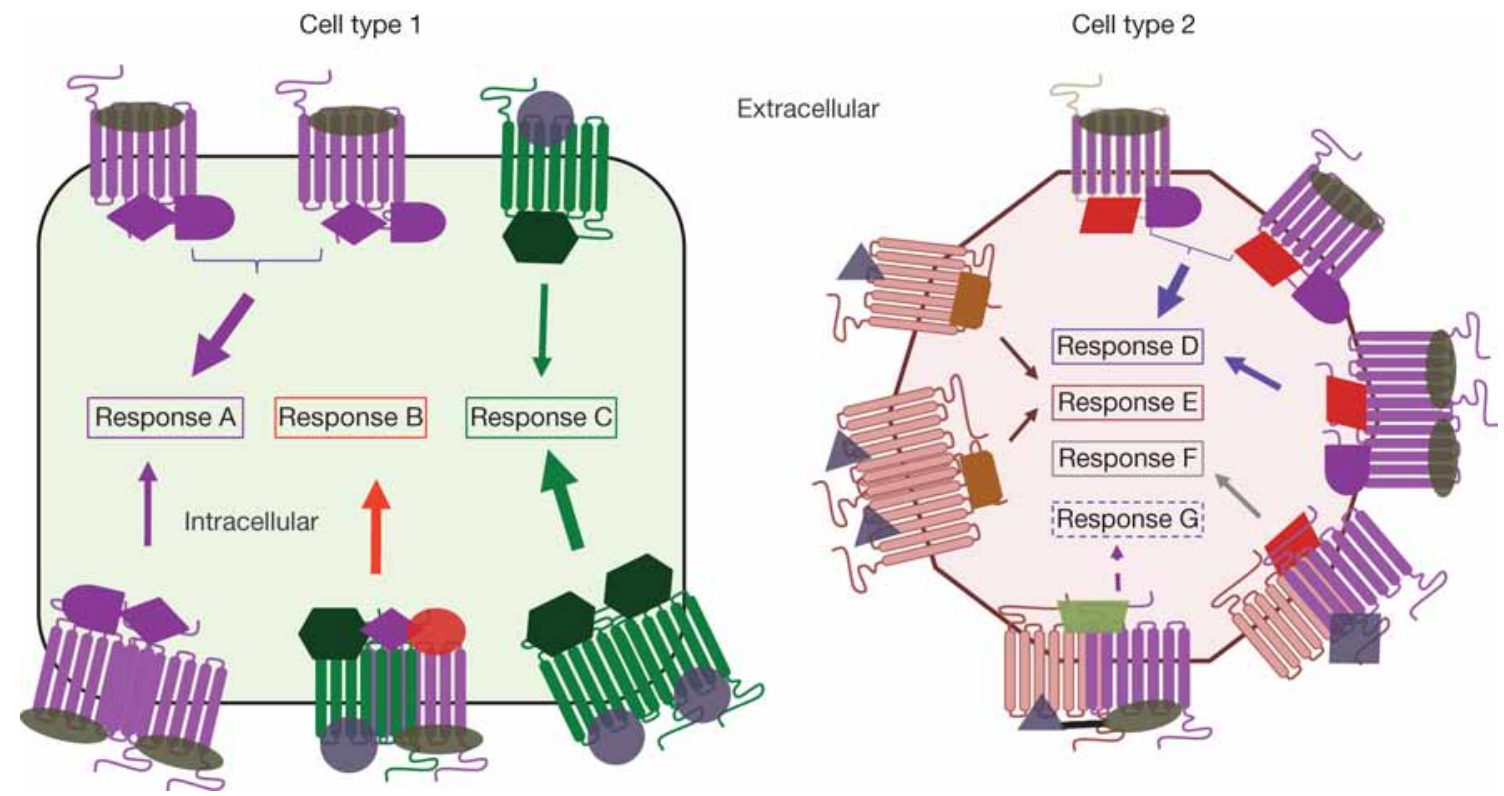

Figure 3

Schematic illustration of different signaling scenarios that potentially occur at GPCRs and GPCR oligomers in different cell types. This scheme illustrates potential scenarios that are feasible concerning receptor signaling and oligomerization in different cell types. Further diverse scenarios and levels of receptor organization are potentially probable but have not been implemented here (e.g. by heterotrimerization). Different intracellular signaling parameters in strength (arrows thin or bold) and constitution (response boxes A-G) are indicated. A particular receptor (e.g. purple) may activate diverse intracellular signaling pathways in different cell types, indicated as cell type 1 (response A) and cell type 2 (response D). In cell type 1, this receptor is capable of activating two different downstream signaling events after ligand binding. This receptor has different properties concerning binding and activation of intracellular effectors in cell type 1 as the set and amount of particular intracellular signaling determinants (e.g. G-protein subtypes or other downstream signaling molecules) differ. Moreover, in each cell type, a multitude of different GPCRs are expressed, indicated as additional green receptors in cell type 1 or of light beige color in cell type 2 . These receptors activate different signaling pathways (responses B and E). In each cell type, orphan receptors with unknown ligand(s) may also occur and influence the system of interacting proteins (not shown). In cell type 1, homooligomerization of the receptors may lead to a lowered signaling (slim arrow) compared with receptor monomer signaling. Receptor oligomerization may lead to enhanced signaling as indicated for the green receptor in cell type 1 (bold arrow). Examples of such differences in signaling responses in dependency of oligomerization or monomerization have been reported in a previous study on the MC4R (Piechowski et al. 2013). Furthermore, there may be heterooligomerization of the receptors (as described for the MC4R), indicated by receptor pairs (mixed color). These interactions should lead to the activation of signaling pathways that are partially identical to each monomer, but may also result in the activation of other signaling events (response C or F). For homo- and heterooligomers, ligand binding properties are known to drastically differ to those of monomers (indicated in heterodimer cell type 2). Moreover, bivalent ligands (illustrated in cell type 2) combine particular ligands for the respective protomers, which may ultimately lead to alterations in the signaling properties of the complex (response G).

signaling properties of interacting protomers (Prinster et al. 2005) such as in ligand binding (Levoye et al. 2006a, Lohse 2010), G-protein coupling selectivity, and signal transduction mechanisms (reviewed in Bouvier 2001, George et al. 2002), or for cell surface expression (Uberti et al. 2005). Functional cross-regulation of G-protein activation may occur (Maurice et al. 2011b), despite the assembly of these GPCRs in heterooligomeric complexes (Nijmeijer et al. 2010).

Specifically, a particular GPCR in a specific cell type can function as a protomer, homomer, or in a heteromeric constellation (Fig. 3). Several functional scenarios of receptor property modifications dependent on oligomerization have been identified or have been suggested, as indicated in the following examples:
1. Constitution of homo- and/or heteromers:

(i) The internalization of heteromers differs from that of homomers or monomers (Hanyaloglu et al. 2002, Kilpatrick et al. 2015).

(ii) Signaling of the monomer is enhanced compared with the oligomer (Piechowski et al. 2013).

(iii) Signaling of the monomer is weaker compared with the oligomer (Wilson et al. 2007, Magalhaes et al. 2010, Pellissier et al. 2011).

2. A homomer is capable of binding various ligands, and/or binding capacities differ compared with the monomer (Durroux 2005).

3. A heteromer, which may also be an orphan receptor (Levoye et al. 2006b), in a given cell type may:

Published by Bioscientifica Ltd. 
(i) activate the same signaling pathways as the protomer(s) (neutral heterooligomeric) (Prinster et al. 2005);

(ii) modulate signaling pathways (e.g. strength of signaling) (AbdAlla et al. 2000, Terrillon et al. 2004);

(iii) activate pathways that differ from both protomers (Hague et al. 2006, Rashid et al. 2007, Gomes et al. 2013);

(iv) bind ligand(s) that differ (e.g. also at allosteric binding sites) (Durroux 2005);

(v) bind artificial ligands that modify signaling pathways such as bivalent ligands (Shonberg et al. 2011, Mohr et al. 2013, Yuan et al. 2013).

\section{How is oligomerization detected experimentally?}

In the last two decades, various methods have been applied to detect GPCR-GPCR interactions (Table 1). Each of these techniques exhibits both advantages and disadvantages when compared with one another and with regard to their aim; however, this field is characterized by strong development and rapid advancement. Because of previous thorough reviews of methods for the detection of oligomers (e.g. Persani et al. 2007, Kaczor \& Selent 2011, Bonomi \& Persani 2013, Gomes et al. 2016), we will not describe the particular methods in detail, but will merely provide a brief overview of commonly used approaches. Currently applied techniques can be subdivided based on their methodological principles or experimental conditions as follows: (i) antibody-based and antibody-independent; (ii) dynamic and nondynamic systems; (iii) analyses of living, fixed or lysed cells; or (iv) in vitro cell culture or an in vivo model. Antibody-based techniques, such as co-immunoprecipitation, co-immunolocalization, sandwich-ELISA or the proximity ligation assay, primarily recognize epitope tags (Table 1). Due to the lack of specific GPCR antibodies, these techniques are often limited to in vitro cell culture overexpression conditions. Homo- or heteromer detection by antibody-based assays are mostly used with differentially epitope-tagged GPCRs and are effective in fixed or lysed cells (reviewed in e.g. Skieterska et al. 2013, Gomes et al. 2014). In the case of antibodies that exist for a specific GPCR or GPCR

Table 1 Methods that have been used to determine di- and oligomerization of GPCRs.

\begin{tabular}{|c|c|c|c|c|}
\hline \multirow[b]{3}{*}{ Method } & \multicolumn{4}{|c|}{ Application } \\
\hline & \multicolumn{2}{|c|}{ In vitro } & \multirow[b]{2}{*}{ In situ } & \multirow[b]{2}{*}{ In vivo } \\
\hline & & In living cells & & \\
\hline \multicolumn{5}{|l|}{ Antibody-based } \\
\hline Co-immunoprecipitation (Co-IP) & + & & $(+)$ & \\
\hline \multicolumn{5}{|l|}{ Co-immunolocalization } \\
\hline Sandwich-ELISA & + & & & \\
\hline $\begin{array}{l}\text { Proximity ligation assays (PLA) } \\
\text { mostly antibody-independent }\end{array}$ & + & & $(+)$ & \\
\hline Proximity biotinylation & + & & & \\
\hline Resonance energy transfer (RET) & + & + & + & \\
\hline \multicolumn{5}{|l|}{ FRET (F, fluorescence), } \\
\hline \multicolumn{5}{|l|}{ e.g. via } \\
\hline \multicolumn{5}{|l|}{-fluorescent ligands or } \\
\hline \multicolumn{5}{|l|}{ - based on SNAP- and CLIP-tag technology } \\
\hline \multicolumn{5}{|l|}{ BRET ( $B$, bioluminescence), } \\
\hline \multicolumn{5}{|l|}{ SRET (S, sequential), } \\
\hline \multicolumn{5}{|l|}{ TR-FRET (TR, time-resolved) } \\
\hline \multicolumn{5}{|l|}{ e.g. via antibody-based HTRF } \\
\hline $\begin{array}{l}\text { Protein complementation assays (PCA) } \\
\text { e.g. based on fluorescent proteins, enzymes, ubiquitin }\end{array}$ & + & + & & \\
\hline Photoactivated localization microscopy (PALM) & + & + & & \\
\hline Fluorescence cross-correlation spectroscopy (FCCS) & + & + & & \\
\hline $\begin{array}{l}\text { Allosteric crosstalk } \\
\text { e.g. via radioligand binding }\end{array}$ & + & + & + & $(+)$ \\
\hline
\end{tabular}

Dimer detection using antibody-based and antibody-independent techniques. Antibody detection primarily requires tagging of GPCRs. Due to the availability of several primary GPCR antibodies and the possibility of tagged GPCR expression in animal models, in situ detection by antibody-based methods may be possible (indicated by bracketed plus symbol). The most promising technique used to detect GPCR-GPCR interactions in the physiological in vivo background is by analyzing allosteric crosstalk. The limitation of this method is the knowledge of adequate ligands, their detailed effects, and tissue specificity (also indicated as bracketed plus symbol). 
oligomer, expression and detection of labeled GPCRs are also possible in animal models.

Elaborate enhancement of methods and constantly refined techniques even allow for the detection of GPCR protomers and oligomers in living cells or tissue samples by some antibody-independent methods. Of these methods, the application of resonance energy transfer (RET) and protein complementation assay (PCA) (for review see e.g. Vidi \& Watts 2009, Lohse et al. 2012, Ng et al. 2012, Bonomi \& Persani 2013, Ciruela et al. 2014, van Unen et al. 2015) have been particularly used to detect GPCR homo- or heteromerization.

Moreover, photo-activated localization microscopy (PALM) and fluorescence fluctuation spectroscopy techniques (FCCS) have been developed (for review see Herrick-Davis et al. 2013, Hink \& Postma 2013). These straightforward methods permit a quantified interaction monitoring of fluorescent-labeled GPCRs at a nanomolar concentration level or even as single molecules without a distance limit for interactions compared with RET.

The most promising methods to detect GPCR homoand heteromerization in in vivo systems are via the analysis of allosteric crosstalk (Durroux 2005, Teitler \& Klein 2012). This method is based on the idea that the dimerization process may lead to crosstalk between interacting GPCRs and may result in cooperative binding of ligands to these protomers. As a prerequisite, sufficient knowledge of the relevant GPCR-ligand interdependency (agonist, antagonist, inverse agonist effects) is required to analyze interactions with this method.

\section{Oligomerization of receptors in endocrine regulation}

Endocrine regulatory circuits consist of releasing hormones secreted from the hypothalamus. These hormones activate their cognate receptors on specialized pituitary cells, which subsequently lead to pituitary hormone release. The anterior pituitary hormones function at their end organs, which may be an endocrine gland. These hormones exert their action or further modulate end-organ hormone secretion, which is regulated in a negative feedback manner to the hypothalamus and the pituitary as it is known for the regulation of growth, thyroid function, fertilityreproduction and adrenal functions. Furthermore, many other endocrine functions such as energy metabolism or glucose homeostasis are tightly regulated by hormone/receptor feedback systems.
What is known about oligomerization of GPCRs involved in endocrine regulation?

Many receptors for releasing hormones and tropic hormones have been suggested to comprise of homo- or heterooligomers, whereby these findings are primarily based on in vitro studies. Although oligomerization of GPCRs is known for several of GPCR subfamilies (Young et al. 2007, Harikumar et al. 2008, Ng et al. 2012, Ng \& Chow 2015), we will focus on several examples from the largest GPCR family, family A, to provide insights into linked aspects.

\section{GPCRs of the pituitary-thyroid axis}

In specific cells, the pituitary thyrotropin-releasing hormone (TRH) binds to the TRH receptor (TRHR) (Sun et al. 2003). In addition to TRHR expression in the pituitary, extrapituitary TRHR localization has also been found in various areas of the brain (Cao et al. 1998, Heuer et al. 1999, Bilek 2000). The TRHR may form homomers (Kroeger et al. 2001) in the absence of the ligand; however, ligand stimulation is suggested to further increase homooligomerization (Kroeger et al. 2001, Zhu et al. 2002). TRHR dimerization was found to affect trafficking but not signaling (Song \& Hinkle 2005) and potentiated hormone-dependent receptor phosphorylation (Song et al. 2007).

There are two different subtypes of TRHR in rodents. These receptor subtypes are able to heterooligomerize, which has been found to change their functional properties in terms of $\beta$-arrestin recruitment (Hanyaloglu et al. 2002).

The secreted hormone thyrotropin (TSH), in turn, activates the thyroid gland via binding to the thyrotropin receptor (TSHR), which induces the production of thyroxine $\left(\mathrm{T}_{4}\right)$ and triiodothyronine $\left(\mathrm{T}_{3}\right)$. The TSHR has been previously reported to homooligomerize (Latif et al. 2001, Davies et al. 2002), which is most likely independent from TSH stimulation (Bonomi \& Persani 2013; Urizar et al. 2005) or constitutive activation by mutation (Zoenen et al. 2012, Biebermann et al. 2012b). In regards to the TSHR, interaction between the receptor protomers occurs at the transmembrane bundle (Urizar et al. 2005), but an additional role of the extracellular domain on the oligomer constitution is proposed based on BRET experiments (Urizar et al. 2005). In the same study, further experimental evidence for negative cooperativity with respect to ligand binding was demonstrated and supports a functional relevance of homomers. This is of general

Published by Bioscientifica Ltd. 
importance to further understand endocrine regulation at a wide range of ligand (hormone) concentrations with the highest level of sensitivity occurring at lower hormone concentrations (Urizar et al. 2005). This is true for physiological TSH concentrations in serum that span one order of magnitude (Bianco et al. 2014). Moreover, a recent study leads to the observation that two TSH molecules bound at a TSHR homodimer are necessary to activate Gq (IP) (Allen et al. 2011). Further support for a functional role of TSHR oligomerization is provided by studies showing dominant negative effects by pathogenic mutations (Calebiro et al. 2005), which can be best explained by mutual interrelations between TSHR protomers.

\section{The receptors of the hypothalamic-pituitary-gonadal (HPG) axis}

The first step in the production and release of the gonadotropins lutropin ( $\mathrm{LH}$ ) and follitropin (FSH) is binding of gonadotropin-releasing hormone $(\mathrm{GnRH})$ to its receptor (GnRHR) in the pituitary. Different studies revealed that the GnRHR is able to form microaggregates (oligomers) due to GnRH stimulation (Conn et al. 1982a,b, Cornea et al. 2001, Kroeger et al. 2001). Evidence of human GnRHR dimerization derives from mutant receptors that inhibit ligand binding and second messenger production of wild-type via a dominant negative effect (Brothers et al. 2004). Interestingly, in the protochordate Ciona intestinalis, which lacks a hypothalamus-pituitary-gonad axis, four different subtypes of GnRHR exist (reviewed in Satake et al. 2013). One of the receptor subtypes (R4) is an orphan receptor and modulates the functionality of a further particular GnRHR receptor subtype in terms of intracellular $\mathrm{Ca} 2+$ elevation and ERK phosphorylation (Sakai et al. 2008). Moreover, GnRHR-mediated cAMP signaling is decreased in the heterodimeric constellation between this orphan GnRHR and another paralog due to a shift from Gs to Gi signaling (Sakai et al. 2012). However, how GnRHR oligomerization influences the expression and secretion of the gonadotropins LH and FSH has not yet been thoroughly investigated (Satake et al. 2013).

The receptors for FSH (FSHR) and LH/CG (LHCGR) play a crucial role in reproductive physiology (Themmen \& Huhtaniemi 2000). First indications for LHCGR oligomerization were achieved from studies where coexpression of binding-deficient (with full signaling capacity) and signaling-inhibited (with diminished binding capacity) receptor fragments partially restored ligand-induced signal generation (Osuga et al. 1997). This was the first indication of a functional interrelation between LHCGR monomers. For the FSHR, transactivation was found to most likely induce biased signaling in terms of the generation of only one of two potentially induced hormone signals, but not both simultaneously (Ji et al. 2004).

In 2004, constitutive and agonist-dependent selfassociation of the LHCGR was demonstrated (Tao et al. 2004, Fanelli 2007) as well as the negative effects of inactive LHCGR mutants on wild-type receptor signaling in oligomeric constellations (Tao et al. 2004). Moreover, the functional rescue of two loss-of-function mice LHCGR mutants, a ligand binding defective and a signaling defective that both suffer from infertility in the homozygous state, was proven (Rivero-Muller et al. 2010), which pointed to a physiological relevance of LHCGR oligomerization and receptor-protomer interplay. Recently, a sophisticated method of single molecule analysis has revealed contacts of interacting LHCGR variants (Jonas et al. 2015).

Furthermore, heteromerization of FSH and LHCGR co-expressed in in vitro cell systems have been observed (Feng et al. 2013, Mazurkiewicz et al. 2015). In granulosa cells, LHCGR and FSHR are co-expressed and LHCGR/FSHR interaction is speculated to play a role during granulosa cell differentiation.

Besides the classical form of endocrine feedback regulation comprising the hormone/receptor systems in the hypothalamus, pituitary, and end-organs, and their feedback regulation, many primary nonendocrine tissues also express and secrete hormones such as leptin and adiponectin (adipocytes), ghrelin (stomach), and PYY cholecystokinin (gut). Action of these hormones is tightly regulated and their receptors are reported to constitute and function as oligomers.

One prominent example is body weight maintenance. The most important pathway of weight regulation is the leptin-melanocortin pathway that communicates peripheral signals to the hypothalamus, where information is integrated to an orchestrated reaction resulting in the maintenance of a constant body weight (Cone 2005, Oswal \& Yeo 2007, Biebermann et al. 2012a, Farooqi 2014). From the periphery, anorexigenic hormones, such as the adipocyte-derived leptin or the pancreatic $\beta$-cell-derived leptin, affect their receptors on neurons of the arcuate nucleus in the hypothalamus (ARC). As a result, the expression of orexigenic peptides, such as neuropeptide Y (NPY) and agouti-related peptide (AgRP), is repressed. Moreover, the expression of pro-opiomelanocortin (POMC) is enhanced, which gives rise to the expression of a

Published by Bioscientifica Ltd. 


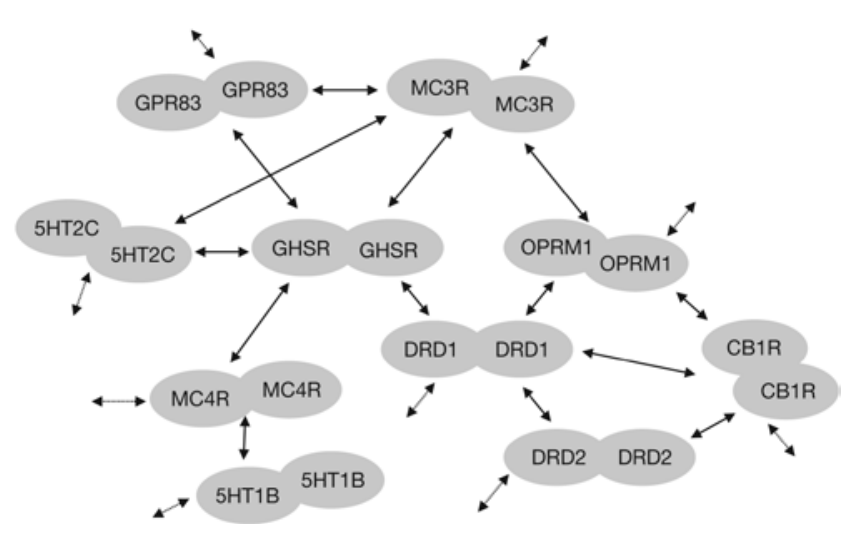

Figure 4

A complex of GPCR homo-/heterodimer interaction networks. Many members of the family A GPCRs have been reported to constitute homodimers and form heteromers (examples used here for this scheme (Pfeiffer et al. 2002, Ramsay et al. 2002, Mandrika et al. 2005, Ellis et al. 2006, Rios et al. 2006, Decaillot et al. 2008, Juhasz et al. 2008, Navarro et al. 2008, Vilardaga et al. 2008, Schellekens et al. 2013, Muller et al. 2013b)). Moreover, several of the so far analyzed subjects are able to heteromerize with different GPCRs such as the ghrelin receptor (GHSR, bold letters) (Jiang et al. 2006, Rediger et al. 2009, 2011, Schellekens et al. 2013). Consequently, the spectrum of potential interaction partners widens the putative modification of physiologically relevant signaling properties in dependency on the GPCR expression pattern in a particular cell type. For a comprehensive overview of available experiments and GPCR oligomer literature, see also the 'The G Protein Coupled ReceptorOligomerization Knowledge Base Project' (Khelashvili et al. 2010). This scheme demonstrates a fragmented section of reported GPCR homoand heteromers, whereby arrows indicate interactions between monomers (Fig. 2C) or homodimers (Ferre 2015) (potentially in constellations as suggested in Fig. 2D iii, iv and v). Dotted arrows indicate potentially more and/or thus far unknown partners. GHSR, ghrelin receptor; MC3R, melanocortin-3 receptor; $5 \mathrm{HT} 2 \mathrm{C}$, 5-hydroxytryptamine (serotonin) receptor 2C; 5HT1B,

5-hydroxytryptamine (serotonin) receptor 1B; GPR83, G-protein-coupled receptor 83; OPRM1, Mu opioid receptor; DRD1/DRD2, dopamine-1 and dopamine-2 receptors; Cb1R, cannabinoid receptor 1 .

variety of additional peptides. Important peptides include $\alpha$ - and $\beta$-melanocyte-stimulating hormones (MSHs) that are capable of activating melanocortin 3 and 4 receptors (MC3R and MC4R) in the ARC and in the nucleus paraventricularis (PVN).

The MC4R, dominantly expressed in the PVN, is the most prominent GPCR in weight regulation (Cone 2005, Biebermann et al. 2012a) and appetite control (Garfield et al. 2015). Investigation of a naturally occurring heterozygous MC4R mutation in a patient suffering from severe early-onset obesity, a dominant-negative effect of the mutant on the wild type was detected, which can be best explained by homomerization of the MC4R and MC4R-MC4R variant (Biebermann et al. 2003). Further support for MC4R oligomerization has been provided by kinetic studies of ligand binding (Kopanchuk et al. 2006). The MC4R is also capable of interacting with other GPCRs that are expressed in the PVN (Fig. 4), although these results have only been indicated in in vitro studies (Rediger et al. 2009). In vivo studies confirming these preliminary results are lacking.

An interesting study on MC4R oligomerization revealed receptor determinants that are involved in the constitution of protomer interfaces. Inhibition of MC4R oligomerization could be achieved by domain substitution using the noninteracting cannabinoid-1 receptor (Piechowski et al. 2013). Substitutions of the MC4R ICL2 and adjacent regions of TMH3 and TMH4, with respective regions of the cannabinoid-1 receptor, lead to partial MC4R dimer dissociation. Most importantly, the signaling capacity was increased in monomeric MC4R variants, which indicates a link between receptor dimerization and the signaling capacity.

In the hypothalamus, the MC3R is expressed on POMC and AgRP/NPY neurons (Barsh etal. 2000, Rediger etal. 2011). The MC3R is known to be embedded in a network of GPCR interactions with e.g. the ghrelin receptor (GHSR) (Fig. 4). Interaction of MC3R with GHSR leads to the upregulation of $\alpha$-MSH-stimulated signaling and the downregulation of basal- and ghrelin-induced GHSR signaling (Rediger et al. 2011). Both the GHSR and the MC3R have been reported to have further diverse GPCR interaction partners (Borroto-Escuela et al. 2014) and also interact with orphan GPCRs such as GPR83 (Muller et al. 2013b). This, in turn, makes predictions of any physiological/functional impact due to modifications at the MC3R, the MC4R, or further interacting partners difficult.

The GPR83 was recently identified as a new determinant involved in body weight regulation (Muller et al. 2013b). So far this orphan receptor is expressed e.g. in the thymus and hypothalamus (Harrigan et al. 1989, 1991, Brezillon et al. 2001). Most importantly, GPR83 has been previously found to be involved in the control of circulating adiponectin levels (De Moerlooze et al. 2000), and Gpr83 expression is decreased in obese mice when compared with lean mice (Muller et al. 2013b). Moreover, GPR83 constitutes homodimers but also has the capacity for heteromerization, as has been demonstrated by heteromerization with the ghrelin receptor (Muller et al. 2013a). Interaction between both receptors leads to inhibition of the GHSR signaling capacity.

The signaling output of the previously mentioned GPCR interaction network (e.g. MC3R, GHSR and GPR83) is most likely crucial for the integration of all peripheral and central signals that are involved in energy metabolism. Future elucidation of combinatorial possibilities will be a matter of experimental confirmation and discussions (Fig. 4).

Published by Bioscientifica Ltd 
Table 2 Examples of GPCR dimers involved in endocrine regulation.

\begin{tabular}{|c|c|}
\hline Homomers & Heteromers \\
\hline \multicolumn{2}{|c|}{ Weight and appetite regulation and/or metabolism } \\
\hline MC3R-MC3R & MC3R-GHSR, NPY2R, MOR \\
\hline MC4R-MC4R & MC4R-5HTR1B, GPR7 \\
\hline GPR83-GPR83 & GPR83-GHSR, MC3R \\
\hline GHSR-GHSR & GHSR-MC3R, GPR83, SSTR5, DRD1/2, 5HTR2C \\
\hline GIPR-GIPR & GIPR-GLPR \\
\hline TAAR1-TAAR1 & TAAR1-ADRA2A, D2R \\
\hline NPY2R-NPY2R & NPY2R-MC3R \\
\hline \multicolumn{2}{|l|}{ NPY1R-NPY1R } \\
\hline \multicolumn{2}{|l|}{ NPY5R-NPY5R } \\
\hline \multicolumn{2}{|l|}{ Reproduction } \\
\hline \multicolumn{2}{|l|}{ PROKR2-PROKR2 } \\
\hline FSHR-FSHR & FSHR-LHCGR \\
\hline LHCGR-LHCGR & LHCGR-FSHR \\
\hline GnRHR-GnRHR & \\
\hline
\end{tabular}

References

(Rediger et al. 2011, 2012)

(Biebermann et al. 2003, Tarnow et al. 2008,

Rediger et al. 2009)

(Muller et al. 2013a,b)

(Rediger et al. 2011, 2012, Kern et al. 2012,

Park et al. 2012, Schellekens et al. 2013,

Muller et al. 2013b)

(Schelshorn et al. 2012, Ng \& Chow 2015)

(Harmeier et al. 2015, Dinter et al. 2015b)

(Dinger et al. 2003, Rediger et al. 2009)

(Dinger et al. 2003)

(Marsango et al. 2011)

(Ji et al. 2002, 2004, Tao et al. 2004, Feng et al. 2013, Mazurkiewicz et al. 2015)

(Ji et al. 2002, 2004, Tao et al. 2004, Feng et al. 2013, Mazurkiewicz et al. 2015)

(Cornea et al. 2001, Kroeger et al. 2001)

This overview represents examples of GPCRs that are involved in endocrine regulation, which have been reported to comprise homo- or heteromers. The examples in brackets are confirmed in their interaction but have not yet been functionally characterized.

Further examples of GPCRs involved in endocrine regulation, which have been reported to oligomerize, are the prokineticin-receptor 2 (PROKR2), the oxytocin receptor (OTR) (Table 2), or dopamine receptor (D2R). Several examples will be provided to pinpoint the complexity and common occurrence of oligomerization.

The OTR and vasopressin receptors (AVPRs: V1aR, V1BR, V2R) belong to a subclass of family A GPCRs. The OTR and OT are involved in memory and learning, stress regulation and anxiety, and aggressive, sexual and maternal behaviors (e.g. Argiolas 1992, Malik et al. 2012, Ebner et al. 2013). Moreover, the OTR is involved in thermoregulation and brain development (Gimpl \& Fahrenholz 2001, Kasahara et al. 2013). In the periphery, the OTR is expressed in the uterus and in the myoepithelial cells of the mammary gland at the end of pregnancy, and plays an important role during labor and milk ejection in a positive feedback manner (Viero et al. 2010). Several diseases or pathogenic conditions are associated with the function of this receptor including autism and schizophrenia (Gimpl \& Fahrenholz 2001). It was recently reported that OTR and vasopressin receptors form homo- and heterodimers in vitro and in vivo (Albizu et al. 2010b). Negative cooperative binding of oxytocin at the OTR was observed in in vitro systems, which points to a functional significance of dimerization (Albizu et al. 2006). It has been suggested that constitutive homodimerization and heterodimerization between the OTR and the V1aR and V2R is established early in the endoplasmatic reticulum (ER) and that ligand binding at the plasma membrane does not modify the dimerization state (Terrillon et al. 2003). Heterodimerization of V1aR and $\mathrm{V} 2 \mathrm{R}$ vasopressin receptors determines the interaction with $\beta$-arrestin and their trafficking patterns (Terrillon et al. 2004). Of note, heteromerization may be of physiological relevance in tissues where the aforementioned receptors are co-expressed, such as heterodimers with the D2 dopamine receptor in the striatum (Romero-Fernandez et al. 2013). Heterodimerization was also reported for OTR and $\beta-2$ adrenergic receptors. This interaction modifies ERK1/2-activation allosterically in dependency of ligand treatment (agonists or antagonists) (Wrzal et al. $2012 a, b)$. Interestingly, direct interactions between V1b and the corticotropin-releasing hormone receptor 1 were recently described (Murat et al. 2012). Via costimulation, this heterodimer mediates a synergistic catecholamine secretion compared with single ligand stimulation. Moreover, vasopressin potentiated CRH-induced cAMP accumulation and CRH potentiated AVD-induced inositol phosphate production. Vasopressin and CRH are both involved in the regulation of adrenocorticotropin and insulin release (Murat et al. 2012).

Four major dopaminergic pathways exist in the central nervous system (CNS). The nigrostriatal system is critical for movement and the mesolimbic and mesocortical neurons play a major role in cognitive functions including feeding, affect, reward, sleep, attention, memory and

Published by Bioscientifica Ltd 
learning (Perreault et al. 2014). Dopamine receptors have been suggested to be divided into two classes related to their signaling capacities (Beaulieu \& Gainetdinov 2011): D1-class receptors (D1 and D5 subtypes) activate the adenylyl cyclase and increase cAMP levels; and D2-class receptors (D2, D3 and D4 subtypes) inactivate the adenylyl cyclase. Regions where the $\mathrm{D} 2 \mathrm{R}$ is expressed include the striatum, nucleus accumbens, olfactory tubercle and hippocampus (Beaulieu \& Gainetdinov 2011). The D2R comprises homomers (Guo et al. 2003, 2005) and a multitude of heteromers (Perreault et al. 2014), e.g. with the D1R, D4R, D5R, adenosine A2 receptor (A2R), serotonin $2 \mathrm{~A}$ receptor (5HT-2AR), OTR, and the histamine H3 receptor (H3R). A functional relevance for the D1R/D2R heterodimer has not yet been confirmed (Frederick et al. 2015). Recently, in vivo relevance for GHSR/D1R interrelation was found to be involved in hippocampal behavior and memory (Kern et al. 2015). Dopaminergic pathways play a critical role in diseases such as Parkinson's disease (nigrostriatal system), schizophrenia, and addiction (mesolimbic and mesocortical system) (Li \& Ma 2013). In schizophrenia, cortical D2Rs may be hypersensitive to dopamine (Seeman et al. 2005, 2007) or present in increased amounts in some regions.

The prokineticin system is related to several physiological and pathological conditions (MaldonadoPerez et al. 2007, Negri et al. 2007, Zhou et al. 2012). Knockout mice models for both ligand and receptor revealed the role of PROK2 signaling in olfactory bulb morphogenesis and sexual maturation, and suggested PROK2 and PROKR2 as strong candidate genes for human GnRH deficiency ( $\mathrm{Ng}$ et al. 2005, Matsumoto et al. 2006). The PROKR2 is involved in the pathogenesis of hypogonadotropic hypogonadism (Dode et al. 2006, Bonomi et al. 2012). Pathogenic germline PROKR2 mutations associated with central hypogonadism have been identified to cause modulation of distinct intracellular pathways (biased signaling modulation) (Libri et al. 2014, Sbai et al. 2014), whereby the PROKR2 wild type activates different G-protein subtypes (Chen et al. 2005). PROKR2 variants have been further described in patients with idiopathic combined pituitary hormone deficits (CPHD) including gonadotropin deficiency (Raivio et al. 2012, Reynaud et al. 2012). The PROKR2 also forms constitutive homomers in vivo (Marsango et al. 2011), and specific protomer-protomer interfaces for the oligomer have been suggested (Sposini et al. 2015). Future investigation of the relationship between oligomerization and pathogenic biased signaling modulation at this receptor is of interest.

\section{GPCRs in interaction with non-GPCR proteins}

In addition to the above-described interactions between GPCRs in homomeric or heteromeric constellations, GPCRs are also able to associate with proteins that are capable of modifying signaling properties. They may impact trafficking or act as allosteric modulators (Maurice et al. 2011a). Furthermore, GPCRs also act as scaffolding proteins that link the receptor to downstream effectors (Walther \& Ferguson 2015). Interacting proteins may interfere with the receptor either on the intracellular site or on the transmembrane spanning proteins and interact with the transmembrane helices (Kristiansen 2004).

\section{Intracellular interacting proteins}

Many interacting proteins exist, modifying the efficacy or mode of signaling and localization of the GPCRs (reviewed in Ritter \& Hall 2009, Maurice et al. 2011a, Walther \& Ferguson 2015). Examples of intracellular proteins can be subdivided into arrestin, PDZ (postsynaptic density 95/disc large/zona occludens-1)-containing proteins, and non-PDZ-containing proteins (Walther \& Ferguson 2015), which are a large group of scaffolding proteins modifying GPCR functions. PDZ-containing proteins are a diverse group of proteins such as the $\mathrm{Na}+-\mathrm{H}+$ exchange regulatory factor (NHERF) (Dunn \& Ferguson 2015), which changes signaling properties from Gs/adenylyl cyclase activation of the parathyroid hormone receptor (PTHR) to Gq/11 phospholipase C signaling (Ardura \& Friedman 2011). For $\beta$-adrenergic receptor 2 (ADRB2), NHERF1 acts as a trigger for receptor resensitization, whereas in the absence of NHERF1, ADRB2 is degraded (Hall et al. 1998). A further example for non-PDZ-containing proteins that modulate GPCR function is the adaptor protein 14-3-3tau, which decreases FSH-induced cAMP accumulation (Cohen et al. 2004). Moreover, lysosomal degradation for the $\delta$-opioid receptor occurs in the presence of an additional type of interacting protein, the GPCR-associated sorting protein 1 (GASP1), whereas in the absence of GASP1, the receptor is resensitized (Whistler et al. 2002).

\section{Interacting transmembrane proteins}

Identification of receptor activity modifying proteins (RAMPs), the single transmembrane-spanning proteins, underline a new mode of the functional regulation of GPCRs. It was initially identified as an obligatory factor for calcitonin gene-related peptide (CGRP) to activate its receptor, the calcitonin receptor-like receptor

Published by Bioscientifica Ltd. 
(CL-R) (McLatchie et al. 1998). Different members of RAMP modify ligand specificity such as RAMP1 associated with CL-R to facilitate CGRP binding; however, association with RAMP2 to CL-R enables adrenomedullin to bind to CL-R (McLatchie et al. 1998). Since then, different members of the RAMP family have been identified. All RAMPs interact with CL-R, the calcitonin and the VPAC1 receptor; however, other GPCRs, such as glucagon or the PTHR, function together with distinct RAMPs (Hay et al. 2006).

The importance of interacting proteins for GPCR function is further evidenced by various examples. Previously, investigation of the functional aspects of the $\mathrm{ACTH}$ receptor (MC2R, melanocortin 2 receptor) in vitro was inconceivable as cell surface expression in different cell types was impossible. This changed with the identification of the melanocortin receptor-associated protein (MRAP) (Metherell et al. 2005), a single transmembrane-spanning protein that escorts the MC2R to the cell surface. Other melanocortin receptors (MC1R, MC3R, MC4R and MC5R) are able to traffic to the cell surface in the absence of interacting proteins; however, melanocortin receptor-associated protein 2 (MRAP2), which is primarily expressed in the hypothalamus, has been identified to influence the function of these MCRs (Cooray \& Clark 2011, Jackson et al. 2015). Moreover, prokineticin receptor-1 (PROKR1) is the first nonmelanocortin GPCR that is regulated by MRAP2 (Chaly et al. 2016). This suggests a new pathway by which MRAP2 regulates energy homeostasis by inhibition of PROKR1.

\section{Existence of direct interactions between GPCRs/ion channels and GPCRs/transporters}

Direct protein-protein interactions have also been reported for GPCRs and ion channels such as KIR channels or voltage-gated calcium channel Cav 2.2 that form a macromolecular ion channel/GPCR signaling complex (Doupnik 2008, Benleulmi-Chaachoua et al. 2016). In turn, this leads to the idea of the possibility for a direct interaction and functional association between GPCRs and further transmembrane-spanning proteins. Channel types such as $\mathrm{Ca} 2+$ ion transporting transient receptor potential channels (TRPs) (Veldhuis et al. 2015) or substrate transporters, such as members of the major facilitator superfamily (MFS) (Law et al. 2008), are known to be closely linked to the function of GPCRs or vice versa. Specific signals from GPCRs located on sensory neurons converge on members of the TRP family, leading to channel sensitization and activation, which amplify e.g. pain, itch and neurogenic inflammation (Veldhuis et al. 2015). On the other hand, several GPCR ligands are transported out of the cell by members of the MFS with 12-transmembrane helices (e.g. dopamine transporter). Furthermore, transporter substrates, such as glucose for cell metabolism, are transported into the cell by MFS members (e.g. glucose transporter (GLUT)). There are few examples that support the notion of a direct GPCR/channel (Yekkirala 2013) or GPCR/transporter interactions, e.g. the observed interplay between the ADRB2, GLUT4 and melatonin 1 receptor/Cav 2.2 (Dehvari et al. 2012, Benleulmi-Chaachoua et al. 2016), or modulation of monoamine transporters by common biogenic amines via the TAAR1 (Xie et al. 2008). Altogether, this raises the possibility that an association between different proteins and GPCRs should be of importance due to a fast mutual or synergistic influence on functional properties. This hypothesis requires further and solid confirmation and validation.

\section{GPCR oligomerization in endocrine dysfunctions}

\section{Is there a direct link between GPCR oligomerization and pathophysiology?}

Malfunctions of approximately 100 GPCRs are associated with various human diseases (Hutchings et al. 2010) including cancer, viral infections, inflammation, infertility, and metabolic and neurological disorders (Seifert \& Wenzel-Seifert 2002, Dorsam \& Gutkind 2007, Garcia-Jimenez \& Santisteban 2007, Schoneberg et al. 2004, Vassart \& Costagliola 2011). Almost 20\% of tumors harbor mutations in GPCRs and approximately $10 \%$ of cancer-related mutations have been identified in G-proteins ( $\mathrm{O}^{\prime}$ Hayre et al. 2013). An overview of the diverse roles of G-protein-coupled receptors (GPCRs) in the pathophysiology of various human diseases, subdivided into associations with obesity, diabetes, cardiovascular diseases, allergies or cancers, can be found in the excellent review by Heng and coworkers (2013). The pathogenic triggers at GPCRs vary from hormonal dysregulation, virus infections, mutations, or interactions with autoantibodies. Interestingly, it was recently reported that 365 human GPCRs are potential drug targets (Garland 2013).

As described in the numerous examples above, oligomerization is a common property for GPCRs (Ferre \& Franco 2010) and can also be addressed to receptors http://jme.endocrinology-journals.org DOI: 10.1530/JME-16-0049
○ 2016 Society for Endocrinology Printed in Great Britain
Published by Bioscientifica Ltd 
involved in endocrine regulation such as the TSHR, LHCGR or MC4R (Table 2). Secondly, oligomerization is of functional relevance, although it has/could not have been rendered more precisely for all the GPCRs described here so far. By combining these two facts, that the correct function of GPCRs correlates with a specific protomer/protomer arrangement, makes it very likely that a dysfunction of GPCR signaling can also be due to modified oligomeric properties, e.g. by mutants in the protomer interfaces or in the ligand binding sites.

Despite the huge and increasing amount of in vitro findings and potentially artificial data, the relevance of GPCR oligomerization in vivo has been confirmed by several examples (Overton \& Blumer 2000) including cases of pathophysiological importance (Tadagaki et al. 2011, 2012b, Tschische et al. 2011, Kern et al. 2015). GPCRs, in relation to neurophysiological processes, are one of the best studied subjects in this field (Gomes et al. 2000, 2013, Prinster et al. 2005, Fuxe et al. 2012). For example, a serotonin/glutamate receptor complex implicated in psychosis has been identified in previous studies and a role for GHSR in modulation of the D1R function in memory and behavior (Gonzalez-Maeso et al. 2008, Kern et al. 2015). Heteromerization between the dopamine receptor subtypes, D1R and D2R, are likely to be implicated in depression (Rashid et al. 2007). The D1R-D2R heterodimer was detected at higher levels in the postmortem striatum of patients than in normal subjects (Pei et al. 2010). Furthermore, the pathophysiological relevance of oligomerization was indicated in a specific case for angiotensin receptor II (AT1R) and bradykinin receptor-2 (B2R). The AT1R-B2R heterodimer is supposed to be functionally correlated with preeclampsia, as this heteromer was observed to be more abundant on platelets from pre-eclamptic women than on platelets from normotensive pregnant women (AbdAlla et al. 2001). Moreover, for the GABAB receptors, signaling activity is inhibited due to ligand-induced monomerization of the obligatory dimers, which has an impact on neuropathic pain sensitization (Laffray et al. 2012).

For GPCRs involved in endocrine regulation, which has omni-relevance in physiology and medicine, the elucidation of heteromeric forms have only recently started to become systematic (e.g. Rediger et al. 2009), with the motivation to investigate the entire 'interactome' and 'signalosome' of particular receptors (Table 2). The homomeric arrangement, even in an oligomer-monomer equilibrium (Lambert 2010), defines e.g. the LHCGR or TSHR per se as complexes. To date, there have been no difficulties in adequately combining or incorporating this property into current and previous mechanistical explanations of activation or inactivation, with few exceptions (Zoenen et al. 2012).

In the GPCRs described here, one particular feature potentially highlights a direct link between oligomerization and loss-of-function phenotypes: the dominant negative effect of reported heterozygote mutants or distinct receptor splice variants. Such dominant negative effects have been observed for numerous GPCRs such as rhodopsin (Kurada \& O'Tousa 1995), AVPR2 (Zhu \& Wess 1998), CCR5 (Benkirane et al. 1997), LHCGR (Tao et al. 2004), TSHR (Calebiro et al. 2005), MC1R (Beaumont et al. 2005), GnRHR (Grosse et al. 1997, Brothers et al. 2004), MC4R (Biebermann et al. 2003, Tarnow et al. 2008), or the prostacyclin receptor (Ibrahim et al. 2010). Dominant negative AT2R receptor oligomers induce G-protein arrest and symptoms of neurodegeneration (AbdAlla et al. 2009). For the aforementioned examples, it is generally assumed that the negative effect of receptor variants is transferred to the wild-type receptor by multimerization with the modified and nonfunctional receptor variant.

For the GHSR, MC3R, MC4R, PROKR2 or GPHRs, the occurrence of loss-of- or gain-of-function mutants in patients with hypo- or hyperfunction have been described (Themmen \& Huhtaniemi 2000, Schoneberg et al. 2004, Tao 2006, 2010, Vassart \& Costagliola 2011, Rediger et al. 2012, Troppmann et al. 2013, Libri et al. 2014, Vassart \& Kleinau 2014). In particular, the mutations may cause different mechanisms at the receptor on the molecular level (excellently reviewed in Vassart \& Costagliola 2011). In case of gain-of-function, constitutively activating mutations (CAMs) or substitutions leading to a loss of ligand selectivity have been described. The interrelated combination of both mechanisms caused by one single side-chain substitution such as that reported for the FSHR (Smits et al. 2003) is also feasible. Inactivating mutants accompanied by a loss-of-function may influence many individual or linked parameters at the receptor or ligand such as decreased expression level or loss of ligand binding capacity. In TSHR, pathogenic mutations lead to diseased conditions such as congenital hypothyroidism or nonautoimmune hyperthyroidism, whereas in the LHCGR, male-limited precocious puberty (by CAMs) or hypogonadism may be associated with inactivating variants, although rare. CAMs of the TSHR have been proven on their impact on oligomerization and a direct modification of oligomeric states has not yet been confirmed (Zoenen et al. 2012, Biebermann et al. 2012b). 
This does not exclude the possibility that natural mutations in other receptors may indeed modulate oligomerization. Moreover, the opportunity that inactivating mutations, or a specific entity, interferes with a proper oligomer function should be considered and systematically proven in future studies.

\section{Open aspects and future perspectives}

Oligomerization is widely accepted to be a pivotal aspect of GPCR function regarding transport, signal transduction, signaling regulation and pharmacology. A certain number of examples for relevant oligomers have been reported and will further increase with the use of advanced methods and by directed in vivo searches for GPCR oligomers. Therefore, it is necessary to take GPCR oligomers into consideration in comprehensively understanding their physiological roles, and to explain interrelated processes such as pathogenic dysfunctions and clinical disorders, and in endocrine regulation. This perspective opens fascinating avenues for potential directed and selective pharmacological interventions. The incorporation of oligomeric receptor models into strategies for GPCR drug discovery and the targeting of homo- or heteromers are both challenging and exciting for the identification of new perspectives on the mechanisms of established or new therapeutic agents. Therefore, studying GPCR oligomerization and related structural-functional consequences, including the physiological relevance, is of importance. This includes the identification of the particular GPCR interaction partners (interactome analyses), which is dependent on physiological parameters such as cell type or developmental stage.

A further major effort in future studies is the dissection of functional effects induced by either monomers or oligomers. This requires forced monomerization and oligomerization of GPCRs, which is currently difficult to achieve. Only a comparison of the properties of monomers, homodimers, and those of wild-type receptor 'mixtures' present in a monomer/oligomer equilibrium will lead to definitive answers for the functionality of the different assembly states (Song et al. 2007, Lambert 2010, Teichmann et al. 2012, 2014, Calebiro et al. 2013). Of specific note, at the cell surface with a high number of expressed GPCRs (likely to range between 10 and 100s, e.g. Regard et al. 2008) or many other transmembrane spanning proteins such as transporters, it must be considered that many different heteromers may indeed exist. Unfortunately, current measurement methods do not simultaneously detect quantitative numbers of homomers, heteromers and monomers. This leaves open the possibility of multiheteromers and multiple equilibriums for different oligomers, expecting diverse oligomers of a particular GPCR at the same time point. Finally, these questions must be tackled in future studies, in line with the importance of elucidating proteins expressed at specific cell types and the further development of methods to study functional oligomers in in vivo systems.

\section{Declaration of interest}

The authors declare that there is no conflict of interest that could be perceived as prejudicing the impartiality of the research reported.

\section{Funding}

This work did not receive any specific grant from any funding agency in the public, commercial or not-for-profit sector.

\section{Acknowledgements}

This work was supported by the Deutsche Forschungsgemeinschaft Bl893/2-2, BI893/5-2, BI893/6-6 and BI893/8-1, the Helmholtz Alliance 'Imaging and Curing Environmental Metabolic Diseases' (ICEMED), WP19 (H Biebermann), and by the Else-Kröner-Fresenius-Stiftung (G Kleinau and H Biebermann, 2014 A114).

\section{References}

AbdAlla S, Lother H \& Quitterer U 2000 AT1-receptor heterodimers show enhanced G-protein activation and altered receptor sequestration. Nature 407 94-98. (doi:10.1038/35024095)

AbdAlla S, Lother H, el Massiery A \& Quitterer U 2001 Increased AT(1) receptor heterodimers in preeclampsia mediate enhanced angiotensin II responsiveness. Nature Medicine 7 1003-1009. (doi:10.1038/nm0901-1003)

AbdAlla S, Lother H, el Missiry A, Sergeev P, Langer A, el Faramawy Y \& Quitterer U 2009 Dominant negative AT2 receptor oligomers induce G-protein arrest and symptoms of neurodegeneration. Journal of Biological Chemistry 284 6566-6574. (doi:10.1074/jbc.M808277200)

Ahuja S \& Smith SO 2009 Multiple switches in G protein-coupled receptor activation. Trends in Pharmacological Sciences 30 494-502.

Albizu L, Balestre MN, Breton C, Pin JP, Manning M, Mouillac B, Barberis C \& Durroux T 2006 Probing the existence of G proteincoupled receptor dimers by positive and negative ligand-dependent cooperative binding. Molecular Pharmacology 70 1783-1791. (doi:10.1124/mol.106.025684)

Albizu L, Cottet M, Kralikova M, Stoev S, Seyer R, Brabet I, Roux T, Bazin H, Bourrier E, Lamarque L, et al. 2010a Time-resolved FRET between GPCR ligands reveals oligomers in native tissues. Nature Chemical Biology 6 587-594. (doi:10.1038/nchembio.396)

Albizu L, Moreno JL, Gonzalez-Maeso J \& Sealfon SC $2010 b$ Heteromerization of $\mathrm{G}$ protein-coupled receptors: relevance to neurological disorders and neurotherapeutics. CNS \& Neurological Disorders - Drug Targets 9 636-650. (doi:10.2174/187152710793361586)

Allen MD, Neumann S \& Gershengorn MC 2011 Occupancy of both sites on the thyrotropin (TSH) receptor dimer is necessary for http://jme.endocrinology-journals.org DOI: 10.1530/JME-16-0049
C 2016 Society for Endocrinology Printed in Great Britain
Published by Bioscientifica Ltd 
phosphoinositide signaling. FASEB Journal 25 3687-3694. (doi:10.1096/fj.11-188961)

Ardura JA \& Friedman PA 2011 Regulation of G protein-coupled receptor function by $\mathrm{Na}+\mathrm{H}+$ exchange regulatory factors. Pharmacological Reviews 63 882-900. (doi:10.1124/pr.110.004176)

Argiolas A 1992 Oxytocin stimulation of penile erection. Pharmacology, site, and mechanism of action. Annals of the New York Academy of Sciences 652 194-203. (doi:10.1111/j.1749-6632.1992.tb34355.x)

Bakker RA, Dees G, Carrillo JJ, Booth RG, Lopez-Gimenez JF, Milligan G, Strange PG \& Leurs R 2004 Domain swapping in the human histamine H1 receptor. Journal of Pharmacology and Experimental Therapeutics 311 131-138. (doi:10.1124/jpet.104.067041)

Barsh GS, Farooqi IS \& O'Rahilly S 2000 Genetics of body-weight regulation. Nature $\mathbf{4 0 4} 644-651$.

Beaulieu JM \& Gainetdinov RR 2011 The physiology, signaling, and pharmacology of dopamine receptors. Pharmacological Reviews $\mathbf{6 3}$ 182-217. (doi:10.1124/pr.110.002642)

Beaumont KA, Newton RA, Smit DJ, Leonard JH, Stow JL \& Sturm RA 2005 Altered cell surface expression of human MC1R variant receptor alleles associated with red hair and skin cancer risk. Human Molecular Genetics 14 2145-2154. (doi:10.1093/hmg/ddi219)

Benkirane M, Jin DY, Chun RF, Koup RA \& Jeang KT 1997 Mechanism of transdominant inhibition of CCR5-mediated HIV-1 infection by ccr5delta32. Journal of Biological Chemistry 272 30603-30606. (doi:10.1074/jbc.272.49.30603)

Benleulmi-Chaachoua A, Chen L, Sokolina K, Wong V, Jurisica I, Emerit MB, Darmon M, Espin A, Stagljar I, Tafelmeyer P, et al. 2016 Protein interactome mining defines melatonin MT1 receptors as integral component of presynaptic protein complexes of neurons. Journal of Pineal Research 60 95-108. (doi:10.1111/jpi.12294)

Bianco AC, Anderson G, Forrest D, Galton VA, Gereben B, Kim BW, Kopp PA, Liao XH, Obregon MJ, Peeters RP, et al. 2014 American Thyroid Association Guide to investigating thyroid hormone economy and action in rodent and cell models. Thyroid 24 88-168. (doi:10.1089/thy.2013.0109)

Biebermann H, Krude H, Elsner A, Chubanov V, Gudermann T \& Gruters A 2003 Autosomal-dominant mode of inheritance of a melanocortin-4 receptor mutation in a patient with severe earlyonset obesity is due to a dominant-negative effect caused by receptor dimerization. Diabetes 52 2984-2988. (doi:10.2337/ diabetes.52.12.2984)

Biebermann H, Kuhnen P, Kleinau G \& Krude H 2012a The neuroendocrine circuitry controlled by POMC, MSH, and AGRP. Handbook of Experimental Pharmacology 209 47-75.

Biebermann H, Winkler F, Handke D, Teichmann A, Gerling B, Cameron F, Eichhorst J, Gruters A, Wiesner B, Kuhnen P, et al. $2012 b$ New pathogenic thyrotropin receptor mutations decipher differentiated activity switching at a conserved helix 6 motif of family A GPCR. Journal of Clinical Endocrinology \& Metabolism 97 E228-E232. (doi:10.1210/jc.2011-2106)

Bilek R 2000 TRH-like peptides in prostate gland and other tissues. Physiological Research 49 (Supplement 1) S19-S26.

Bonomi M \& Persani L 2013 Modern methods to investigate the oligomerization of glycoprotein hormone receptors (TSHR, LHR, FSHR). Methods in Enzymology 521 367-383. (doi:10.1016/B978-0-12391862-8.00020-X)

Bonomi M, Libri DV, Guizzardi F, Guarducci E, Maiolo E, Pignatti E, Asci R, Persani L, Idiopathic Central Hypogonadism Study Group of the Italian Societies of Endocrinology, Pediatric Endocrinology and Diabetes, et al. $2012 \mathrm{New}$ understandings of the genetic basis of isolated idiopathic central hypogonadism. Asian Journal of Andrology 14 49-56. (doi:10.1038/aja.2011.68)

Borroto-Escuela DO, Brito I, Romero-Fernandez W, Di Palma M, Oflijan J, Skieterska K, Duchou J, Van Craenenbroeck K, SuarezBoomgaard D, Rivera A, et al. 2014 The G protein-coupled receptor heterodimer network (GPCR-HetNet) and its hub components.
International Journal of Molecular Sciences 15 8570-8590. (doi:10.3390/ ijms15058570)

Bouvier M 2001 Oligomerization of G-protein-coupled transmitter receptors. Nature Reviews Neuroscience 2 274-286. (doi:10.1038/ 35067575)

Brezillon S, Detheux M, Parmentier M, Hokfelt T \& Hurd YL 2001 Distribution of an orphan G-protein coupled receptor (JP05) mRNA in the human brain. Brain Research 921 21-30. (doi:10.1016/S00068993(01)03068-2)

Brothers SP, Cornea A, Janovick JA \& Conn PM 2004 Human loss-offunction gonadotropin-releasing hormone receptor mutants retain wild-type receptors in the endoplasmic reticulum: molecular basis of the dominant-negative effect. Molecular Endocrinology 18 1787-1797. (doi:10.1210/me.2004-0091)

Calebiro D, de Filippis T, Lucchi S, Covino C, Panigone S, Beck-Peccoz P, Dunlap D \& Persani L 2005 Intracellular entrapment of wild-type TSH receptor by oligomerization with mutants linked to dominant TSH resistance. Human Molecular Genetics 14 2991-3002. (doi:10.1093/hmg/ddi329)

Calebiro D, Rieken F, Wagner J, Sungkaworn T, Zabel U, Borzi A, Cocucci E, Zurn A \& Lohse MJ 2013 Single-molecule analysis of fluorescently labeled G-protein-coupled receptors reveals complexes with distinct dynamics and organization. PNAS 110 743-748. (doi:10.1073/pnas.1205798110)

Cao J, O'Donnell D, Vu H, Payza K, Pou C, Godbout C, Jakob A, Pelletier M, Lembo P, Ahmad S, et al. 1998 Cloning and characterization of a cDNA encoding a novel subtype of rat thyrotropin-releasing hormone receptor. Journal of Biological Chemistry 273 32281-32287. (doi:10.1074/jbc.273.48.32281)

Carlsson J, Coleman RG, Setola V, Irwin JJ, Fan H, Schlessinger A, Sali A, Roth BL \& Shoichet BK 2011 Ligand discovery from a dopamine D3 receptor homology model and crystal structure. Nature Chemical Biology 7 769-778. (doi:10.1038/nchembio.662)

Carrillo JJ, Lopez-Gimenez JF \& Milligan G 2004 Multiple interactions between transmembrane helices generate the oligomeric alpha1badrenoceptor. Molecular Pharmacology 66 1123-1137. (doi:10.1124/ mol.104.001586)

Chaly AL, Srisai D, Gardner EE \& Sebag JA 2016 The Melanocortin receptor accessory protein 2 promotes food intake through inhibition of the prokineticin receptor-1. Elife $\mathbf{5}$ pii: e12397.

Chen J, Kuei C, Sutton S, Wilson S, Yu J, Kamme F, Mazur C, Lovenberg T \& Liu C 2005 Identification and pharmacological characterization of prokineticin 2 beta as a selective ligand for prokineticin receptor 1. Molecular Pharmacology 67 2070-2076. (doi:10.1124/mol.105.011619)

Ciruela F, Vilardaga JP \& Fernandez-Duenas V 2010 Lighting up multiprotein complexes: lessons from GPCR oligomerization. Trends in Biotechnology 28 407-415. (doi:10.1016/j.tibtech.2010.05.002)

Ciruela F, Jacobson KA \& Fernandez-Duenas V 2014 Portraying G protein-coupled receptors with fluorescent ligands. ACS Chemical Biology 9 1918-1928. (doi:10.1021/cb5004042)

Cohen BD, Nechamen CA \& Dias JA 2004 Human follitropin receptor (FSHR) interacts with the adapter protein 14-3-3tau. Molecular and Cellular Endocrinology 220 1-7. (doi:10.1016/j.mce.2004.04.012)

Cone RD 2005 Anatomy and regulation of the central melanocortin system. Nature Neuroscience 8 571-578. (doi:10.1038/nn1455)

Conn PM, Rogers DC \& McNeil R 1982a Potency enhancement of a GnRH agonist: GnRH-receptor microaggregation stimulates gonadotropin release. Endocrinology 111 335-337. (doi:10.1210/endo111-1-335)

Conn PM, Rogers DC, Stewart JM, Neidel J \& Sheffield T $1982 b$ Conversion of a gonadotropin releasing hormone antagonist to an agonist. Nature 296 653-655. (doi:10.1038/296653a0)

Cooray SN \& Clark AJ 2011 Melanocortin receptors and their accessory proteins. Molecular and Cellular Endocrinology 331 215-221. (doi:10.1016/j.mce.2010.07.015)

Published by Bioscientifica Ltd. 
Cornea A, Janovick JA, Maya-Nunez G \& Conn PM 2001 Gonadotropinreleasing hormone receptor microaggregation. Rate monitored by fluorescence resonance energy transfer. Journal of Biological Chemistry 276 2153-2158. (doi:10.1074/jbc.M007850200)

Davies T, Marians R \& Latif R 2002 The TSH receptor reveals itself. Journal of Clinical Investigation 110 161-164. (doi:10.1172/ JCI0216234)

De Moerlooze L, Williamson J, Liners F, Perret J \& Parmentier M 2000 Cloning and chromosomal mapping of the mouse and human genes encoding the orphan glucocorticoid-induced receptor (GPR83). Cytogenetics and Cell Genetics 90 146-150. (doi:10.1159/000015650)

Decaillot FM, Rozenfeld R, Gupta A \& Devi LA 2008 Cell surface targeting of mu-delta opioid receptor heterodimers by RTP4. PNAS 105 16045-16050. (doi:10.1073/pnas.0804106105)

Dehvari N, Hutchinson DS, Nevzorova J, Dallner OS, Sato M, Kocan M, Merlin J, Evans BA, Summers RJ \& Bengtsson T 2012 beta(2)Adrenoceptors increase translocation of GLUT4 via GPCR kinase sites in the receptor C-terminal tail. British Journal of Pharmacology 165 1442-1456. (doi:10.1111/j.1476-5381.2011.01647.x)

Deupi X \& Standfuss J 2011 Structural insights into agonist-induced activation of G-protein-coupled receptors. Current Opinion in Structural Biology 21 541-551. (doi:10.1016/j.sbi.2011.06.002)

Dinger MC, Bader JE, Kobor AD, Kretzschmar AK \& Beck-Sickinger AG 2003 Homodimerization of neuropeptide y receptors investigated by fluorescence resonance energy transfer in living cells. Journal of Biological Chemistry 278 10562-10571. (doi:10.1074/jbc. M205747200)

Dinter J, Khajavi N, Muhlhaus J, Wienchol CL, Coster M, Hermsdorf T, Staubert C, Kohrle J, Schoneberg T, Kleinau G, et al. 2015a The multitarget ligand 3-iodothyronamine modulates beta-adrenergic receptor 2 signaling. European Thyroid Journal 4 21-29.

Dinter J, Muhlhaus J, Jacobi SF, Wienchol CL, Coster M, Meister J, Hoefig CS, Muller A, Kohrle J, Gruters A, et al. 2015b 3-iodothyronamine differentially modulates alpha-2A-adrenergic receptor-mediated signaling. Journal of Molecular Endocrinology $\mathbf{5 4}$ 205-216.

Dode C, Teixeira L, Levilliers J, Fouveaut C, Bouchard P, Kottler ML, Lespinasse J, Lienhardt-Roussie A, Mathieu M, Moerman A, et al. 2006 Kallmann syndrome: mutations in the genes encoding prokineticin-2 and prokineticin receptor-2. PLoS Genetics 2 e175.

Dorsam RT \& Gutkind JS 2007 G-protein-coupled receptors and cancer. Nature Reviews Cancer 7 79-94. (doi:10.1038/nrc2069)

Doupnik CA 2008 GPCR-Kir channel signaling complexes: defining rules of engagement. Journal of Receptors and Signal Transduction Research 28 83-91. (doi:10.1080/10799890801941970)

Dunn HA \& Ferguson SS 2015 PDZ Protein regulation of G proteincoupled receptor trafficking and signaling pathways. Molecular Pharmacology 88 624-639. (doi:10.1124/mol.115.098509)

Durroux T 2005 Principles: a model for the allosteric interactions between ligand binding sites within a dimeric GPCR. Trends in Pharmacological Sciences 26 376-384. (doi:10.1016/j. tips.2005.05.006)

Ebner NC, Maura GM, Macdonald K, Westberg L \& Fischer H 2013 Oxytocin and socioemotional aging: Current knowledge and future trends. Frontiers in Human Neuroscience $\mathbf{7} 487$.

Ellis J, Pediani JD, Canals M, Milasta S \& Milligan G 2006 Orexin-1 receptor-cannabinoid $\mathrm{CB} 1$ receptor heterodimerization results in both ligand-dependent and -independent coordinated alterations of receptor localization and function. Journal of Biological Chemistry $\mathbf{2 8 1}$ 38812-38824. (doi:10.1074/jbc.M602494200)

Fanelli F 2007 Dimerization of the lutropin receptor: insights from computational modeling. Molecular and Cellular Endocrinology 260-262 59-64.

Farooqi S 2014 Genetic strategies to understand physiological pathways regulating body weight. Mammalian Genome 25 377-383. (doi:10.1007/s00335-014-9541-z)
Feng X, Zhang M, Guan R \& Segaloff DL 2013 Heterodimerization between the lutropin and follitropin receptors is associated with an attenuation of hormone-dependent signaling. Endocrinology 154 3925-3930. (doi:10.1210/en.2013-1407)

Ferre S 2015 The GPCR heterotetramer: challenging classical pharmacology. Trends in Pharmacological Sciences 36 145-152. (doi:10.1016/j.tips.2015.01.002)

Ferre S \& Franco R 2010 Oligomerization of G-protein-coupled receptors: a reality. Current Opinion in Pharmacology 10 1-5. (doi:10.1016/j. coph.2009.11.002)

Frederick AL, Yano H, Trifilieff P, Vishwasrao HD, Biezonski D, Meszaros J, Urizar E, Sibley DR, Kellendonk C, Sonntag KC, et al. 2015 Evidence against dopamine D1/D2 receptor heteromers. Molecular Psychiatry 20 1373-1385. (doi:10.1038/mp.2014.166)

Fredriksson R \& Schioth HB 2005 The repertoire of G-protein-coupled receptors in fully sequenced genomes. Molecular Pharmacology 67 1414-1425. (doi:10.1124/mol.104.009001)

Fredriksson R, Lagerstrom MC, Lundin LG \& Schioth HB 2003 The G-protein-coupled receptors in the human genome form five main families. Phylogenetic analysis, paralogon groups, and fingerprints. Molecular Pharmacology 63 1256-1272.

Fuxe K, Borroto-Escuela DO, Marcellino D, Romero-Fernandez W, Frankowska M, Guidolin D, Filip M, Ferraro L, Woods AS, Tarakanov A, et al. 2012 GPCR heteromers and their allosteric receptor-receptor interactions. Current Medicinal Chemistry 19 356363. (doi:10.2174/092986712803414259)

Galandrin S, Oligny-Longpre G \& Bouvier M 2007 The evasive nature of drug efficacy: implications for drug discovery. Trends in Pharmacological Sciences 28 423-430. (doi:10.1016/j.tips.2007.06.005)

Garcia-Jimenez C \& Santisteban P 2007 TSH signalling and cancer. Arquivos Brasileiros de Endocrinologia \& Metabologia 51 654-671.

Garfield AS, Li C, Madara JC, Shah BP, Webber E, Steger JS, Campbell JN, Gavrilova O, Lee CE, Olson DP, et al. 2015 A neural basis for melanocortin-4 receptor-regulated appetite. Nature Neuroscience 18 863-871. (doi:10.1038/nn.4011)

Garland SL 2013 Are GPCRs still a source of new targets? Journal of Biomolecular Screening 18 947-966. (doi:10.1177/1087057113498418)

George SR, Lee SP, Varghese G, Zeman PR, Seeman P, Ng GY \& O'Dowd BF 1998 A transmembrane domain-derived peptide inhibits D1 dopamine receptor function without affecting receptor oligomerization. Journal of Biological Chemistry 273 30244-30248. (doi:10.1074/jbc.273.46.30244)

George SR, O'Dowd BF \& Lee SP 2002 G-protein-coupled receptor oligomerization and its potential for drug discovery. Nature Reviews Drug Discovery 1 808-820. (doi:10.1038/nrd913)

Gimpl G \& Fahrenholz F 2001 The oxytocin receptor system: structure, function, and regulation. Physiological Reviews 81 629-683.

Gomes I, Jordan BA, Gupta A, Trapaidze N, Nagy V \& Devi LA 2000 Heterodimerization of $\mathrm{mu}$ and delta opioid receptors: a role in opiate synergy. Journal of Neuroscience 20 RC110.

Gomes I, Fujita W, Chandrakala MV \& Devi LA 2013 Disease-specific heteromerization of G-protein-coupled receptors that target drugs of abuse. Progress in Molecular Biology and Translational Science 117 207265. (doi:10.1016/B978-0-12-386931-9.00009-X)

Gomes I, Gupta A, Bushlin I \& Devi LA 2014 Antibodies to probe endogenous $\mathrm{G}$ protein-coupled receptor heteromer expression, regulation, and function. Frontiers in Pharmacology 5268.

Gomes I, Ayoub MA, Fujita W, Jaeger WC, Pfleger KD \& Devi LA 2016 $\mathrm{G}$ protein-coupled receptor heteromers. Annual Review of Pharmacology and Toxicology 56 403-425. (doi:10.1146/annurevpharmtox-011613-135952)

Gonzalez S, Moreno-Delgado D, Moreno E, Perez-Capote K, Franco R, Mallol J, Cortes A, Casado V, Lluis C, Ortiz J, et al. 2012 Circadianrelated heteromerization of adrenergic and dopamine $\mathrm{D}(4)$ receptors modulates melatonin synthesis and release in the pineal gland. PLoS Biology 10 e1001347.

Published by Bioscientifica Ltd. 
Gonzalez-Maeso J, Ang RL, Yuen T, Chan P, Weisstaub NV, LopezGimenez JF, Zhou M, Okawa Y, Callado LF, Milligan G, et al. 2008 Identification of a serotonin/glutamate receptor complex implicated in psychosis. Nature 452 93-97. (doi:10.1038/nature06612)

Gorinski N, Kowalsman N, Renner U, Wirth A, Reinartz MT, Seifert R, Zeug A, Ponimaskin E \& Niv MY 2012 Computational and experimental analysis of the transmembrane domain $4 / 5$ dimerization interface of the serotonin 5-HT(1A) receptor. Molecular Pharmacology 82 448-463. (doi:10.1124/mol.112.079137)

Grosse R, Schoneberg T, Schultz G \& Gudermann T 1997 Inhibition of gonadotropin-releasing hormone receptor signaling by expression of a splice variant of the human receptor. Molecular Endocrinology 11 1305-1318. (doi:10.1210/mend.11.9.9966)

Guo W, Shi L \& Javitch JA 2003 The fourth transmembrane segment forms the interface of the dopamine D2 receptor homodimer. Journal of Biological Chemistry 278 4385-4388. (doi:10.1074/jbc.C200679200)

Guo W, Shi L, Filizola M, Weinstein H \& Javitch JA 2005 Crosstalk in $G$ protein-coupled receptors: changes at the transmembrane homodimer interface determine activation. PNAS 102 17495-17500. (doi:10.1073/pnas.0508950102)

Guo W, Urizar E, Kralikova M, Mobarec JC, Shi L, Filizola M \& Javitch JA 2008 Dopamine D2 receptors form higher order oligomers at physiological expression levels. EMBO Journal 27 2293-2304. (doi:10.1038/emboj.2008.153)

Hague C, Lee SE, Chen Z, Prinster SC, Hall RA \& Minneman KP 2006 Heterodimers of alpha1B- and alpha1D-adrenergic receptors form a single functional entity. Molecular Pharmacology 69 45-55.

Hall RA, Premont RT, Chow CW, Blitzer JT, Pitcher JA, Claing A, Stoffel RH, Barak LS, Shenolikar S, Weinman EJ, et al. 1998 The beta2-adrenergic receptor interacts with the $\mathrm{Na}+/ \mathrm{H}+$-exchanger regulatory factor to control $\mathrm{Na}+/ \mathrm{H}+$ exchange. Nature 392 626-630. (doi:10.1038/33458)

Hanson MA \& Stevens RC 2009 Discovery of new GPCR biology: one receptor structure at a time. Structure 17 8-14. (doi:10.1016/j. str.2008.12.003)

Hanyaloglu AC, Seeber RM, Kohout TA, Lefkowitz RJ \& Eidne KA 2002 Homo- and hetero-oligomerization of thyrotropin-releasing hormone (TRH) receptor subtypes. Differential regulation of beta-arrestins 1 and 2. Journal of Biological Chemistry 277 50422-50430. (doi:10.1074/ jbc.M209340200)

Harikumar KG, Morfis MM, Sexton PM \& Miller LJ 2008 Pattern of intra-family hetero-oligomerization involving the G-protein-coupled secretin receptor. Journal of Molecular Neuroscience 36 279-285. (doi:10.1007/s12031-008-9060-z)

Harmeier A, Obermueller S, Meyer CA, Revel FG, Buchy D, Chaboz S, Dernick G, Wettstein JG, Iglesias A, Rolink A, et al. 2015 Trace amine-associated receptor 1 activation silences GSK3beta signaling of TAAR1 and D2R heteromers. European Neuropsychopharmacology 25 2049-2061. (doi:10.1016/j.euroneuro.2015.08.011)

Harrigan MT, Baughman G, Campbell NF \& Bourgeois S 1989 Isolation and characterization of glucocorticoid- and cyclic AMP-induced genes in T lymphocytes. Molecular and Cellular Biology 9 3438-3446. (doi:10.1128/MCB.9.8.3438)

Harrigan MT, Campbell NF \& Bourgeois S 1991 Identification of a gene induced by glucocorticoids in murine T-cells: a potential G proteincoupled receptor. Molecular Endocrinology 5 1331-1338. (doi:10.1210/ mend-5-9-1331)

Hay DL, Poyner DR \& Sexton PM 2006 GPCR modulation by RAMPs. Pharmacology \& Therapeutics 109 173-197.

Hebert TE, Moffett S, Morello JP, Loisel TP, Bichet DG, Barret C \& Bouvier M 1996 A peptide derived from a beta2-adrenergic receptor transmembrane domain inhibits both receptor dimerization and activation. Journal of Biological Chemistry 271 16384-16392. (doi:10.1074/jbc.271.27.16384)

Heng BC, Aubel D \& Fussenegger M 2013 An overview of the diverse roles of G-protein coupled receptors (GPCRs) in the pathophysiology of various human diseases. Biotechnology Advances 31 1676-1694. (doi:10.1016/j.biotechadv.2013.08.017)

Hern JA, Baig AH, Mashanov GI, Birdsall B, Corrie JE, Lazareno S, Molloy JE \& Birdsall NJ 2010 Formation and dissociation of M1 muscarinic receptor dimers seen by total internal reflection fluorescence imaging of single molecules. PNAS 107 2693-2698. (doi:10.1073/pnas.0907915107)

Hernanz-Falcon P, Rodriguez-Frade JM, Serrano A, Juan D, del Sol A, Soriano SF, Roncal F, Gomez L, Valencia A, Martinez AC, et al. 2004 Identification of amino acid residues crucial for chemokine receptor dimerization. Nature Immunology 5 216-223. (doi:10.1038/ni1027)

Herrick-Davis K, Grinde E, Cowan A \& Mazurkiewicz JE 2013 Fluorescence correlation spectroscopy analysis of serotonin, adrenergic, muscarinic, and dopamine receptor dimerization: the oligomer number puzzle. Molecular Pharmacology 84 630-642. (doi:10.1124/mol.113.087072)

Heuer H, Schafer MK \& Bauer K 1999 Thyrotropin-releasing hormone (TRH), a signal peptide of the central nervous system. Acta Medica Austriaca 26 119-122.

Hink MA \& Postma M 2013 Monitoring receptor oligomerization by line-scan fluorescence cross-correlation spectroscopy. Methods in Cell Biology 117 197-212. (doi:10.1016/B978-0-12-408143-7.00011-6)

Ho MK, Su Y, Yeung WW \& Wong YH 2009 Regulation of transcription factors by heterotrimeric G proteins. Current Molecular Pharmacology 2 19-31. (doi:10.2174/1874467210902010019)

Hofmann KP, Scheerer P, Hildebrand PW, Choe HW, Park JH, Heck M \& Ernst OP 2009 A G protein-coupled receptor at work: the rhodopsin model. Trends in Biochemical Sciences 34 540-552. (doi:10.1016/j. tibs.2009.07.005)

Hopkins AL \& Groom CR 2002 The druggable genome. Nature Reviews Drug Discovery 1 727-730. (doi:10.1038/nrd892)

Hu J, Hu K, Liu T, Stern MK, Mistry R, Challiss RA, Costanzi S \& Wess J 2013 Novel structural and functional insights into M3 muscarinic receptor dimer/oligomer formation. Journal of Biological Chemistry 288 34777-34790. (doi:10.1074/jbc.M113.503714)

Hutchings CJ, Koglin M \& Marshall FH 2010 Therapeutic antibodies directed at $\mathrm{G}$ protein-coupled receptors. $m A b s$ 2 594-606. (doi:10.4161/mabs.2.6.13420)

Ibrahim S, Tetruashvily M, Frey AJ, Wilson SJ, Stitham J, Hwa J \& Smyth EM 2010 Dominant negative actions of human prostacyclin receptor variant through dimerization: implications for cardiovascular disease. Arteriosclerosis, Thrombosis, and Vascular Biology 30 1802-1809. (doi:10.1161/ATVBAHA.110.208900)

Jackson DS, Ramachandrappa S, Clark AJ \& Chan LF 2015 Melanocortin receptor accessory proteins in adrenal disease and obesity. Frontiers in Neuroscience 9213.

Ji I, Lee C, Song Y, Conn PM \& Ji TH 2002 Cis- and trans-activation of hormone receptors: the LH receptor. Molecular Endocrinology 16 1299-1308. (doi:10.1210/mend.16.6.0852)

Ji I, Lee C, Jeoung M, Koo Y, Sievert GA \& Ji TH 2004 Trans-activation of mutant follicle-stimulating hormone receptors selectively generates only one of two hormone signals. Molecular Endocrinology 18 968-978. (doi:10.1210/me.2003-0443)

Jiang H, Betancourt L \& Smith RG 2006 Ghrelin amplifies dopamine signaling by cross talk involving formation of growth hormone secretagogue receptor/dopamine receptor subtype 1 heterodimers. Molecular Endocrinology 20 1772-1785. (doi:10.1210/me.2005-0084)

Jonas KC, Fanelli F, Huhtaniemi IT \& Hanyaloglu AC 2015 Single molecule analysis of functionally asymmetric $\mathrm{G}$ protein-coupled receptor (GPCR) oligomers reveals diverse spatial and structural assemblies. Journal of Biological Chemistry 290 3875-3892. (doi:10.1074/jbc.M114.622498)

Juhasz JR, Hasbi A, Rashid AJ, So CH, George SR \& O’Dowd BF 2008 $\mathrm{Mu}$-opioid receptor heterooligomer formation with the dopamine D1 receptor as directly visualized in living cells. European Journal of Pharmacology 581 235-243. (doi:10.1016/j.ejphar.2007.11.060) 
Kaczor AA \& Selent J 2011 Oligomerization of G protein-coupled receptors: biochemical and biophysical methods. Current Medicinal Chemistry 18 4606-4634. (doi:10.2174/092986711797379285)

Kasahara Y, Sato K, Takayanagi Y, Mizukami H, Ozawa K, Hidema S, So KH, Kawada T, Inoue N, Ikeda I, et al. 2013 Oxytocin receptor in the hypothalamus is sufficient to rescue normal thermoregulatory function in male oxytocin receptor knockout mice. Endocrinology 154 4305-4315. (doi:10.1210/en.2012-2206)

Kasai RS, Suzuki KG, Prossnitz ER, Koyama-Honda I, Nakada C, Fujiwara TK \& Kusumi A 2011 Full characterization of GPCR monomer-dimer dynamic equilibrium by single molecule imaging. Journal of Cell Biology 192 463-480. (doi:10.1083/jcb.201009128)

Kern A, Albarran-Zeckler R, Walsh HE \& Smith RG 2012 Apo-ghrelin receptor forms heteromers with DRD2 in hypothalamic neurons and is essential for anorexigenic effects of DRD2 agonism. Neuron $\mathbf{7 3}$ 317-332. (doi:10.1016/j.neuron.2011.10.038)

Kern A, Mavrikaki M, Ullrich C, Albarran-Zeckler R, Brantley AF \& Smith RG 2015 Hippocampal dopamine/DRD1 signaling dependent on the ghrelin receptor. Cell 163 1176-1190. (doi:10.1016/j. cell.2015.10.062)

Khelashvili G, Dorff K, Shan J, Camacho-Artacho M, Skrabanek L, Vroling B, Bouvier M, Devi LA, George SR, Javitch JA, et al. 2010 GPCR-OKB: the G protein coupled receptor oligomer knowledge base. Bioinformatics 26 1804-1805. (doi:10.1093/bioinformatics/btq264)

Kilpatrick LE, Humphrys LJ \& Holliday ND 2015 A G protein-coupled receptor dimer imaging assay reveals selectively modified pharmacology of neuropeptide Y Y1/Y5 receptor heterodimers. Molecular Pharmacology 87 718-732. (doi:10.1124/mol.114.095356)

Kleinau G \& Krause G 2009 Thyrotropin and homologous glycoprotein hormone receptors: structural and functional aspects of extracellular signaling mechanisms. Endocrine Reviews 30 133-151. (doi:10.1210/ er.2008-0044)

Kleinau G, Pratzka J, Nurnberg D, Gruters A, Fuhrer-Sakel D, Krude H, Kohrle J, Schoneberg T \& Biebermann H 2011 Differential modulation of Beta-adrenergic receptor signaling by trace amineassociated receptor 1 agonists. PLOS ONE 6 e27073.

Kleinau G, Neumann S, Gruters A, Krude H \& Biebermann H 2013 Novel insights on thyroid-stimulating hormone receptor signal transduction. Endocrine Reviews 34 691-724. (doi:10.1210/er.20121072)

Kobilka BK \& Deupi X 2007 Conformational complexity of G-proteincoupled receptors. Trends in Pharmacological Sciences 28 397-406. (doi:10.1016/j.tips.2007.06.003)

Kobilka B \& Schertler GF 2008 New G-protein-coupled receptor crystal structures: insights and limitations. Trends in Pharmacological Sciences 29 79-83. (doi:10.1016/j.tips.2007.11.009)

Kontoyianni M \& Liu Z 2012 Structure-based design in the GPCR target space. Current Medicinal Chemistry 19 544-556. (doi:10.2174/0929867 12798918824)

Kopanchuk S, Veiksina S, Mutulis F, Mutule I, Yahorava S, Mandrika I, Petrovska R, Rinken A \& Wikberg JE 2006 Kinetic evidence for tandemly arranged ligand binding sites in melanocortin 4 receptor complexes. Neurochemistry International 49 533-542. (doi:10.1016/j. neuint.2006.04.006)

Kristiansen K 2004 Molecular mechanisms of ligand binding, signaling, and regulation within the superfamily of G-protein-coupled receptors: molecular modeling and mutagenesis approaches to receptor structure and function. Pharmacology \& Therapeutics 103 21-80.

Kroeger KM, Hanyaloglu AC, Seeber RM, Miles LE \& Eidne KA 2001 Constitutive and agonist-dependent homo-oligomerization of the thyrotropin-releasing hormone receptor. Detection in living cells using bioluminescence resonance energy transfer. Journal of Biological Chemistry 276 12736-12743. (doi:10.1074/jbc.M011311200)

Kurada P \& O'Tousa JE 1995 Retinal degeneration caused by dominant rhodopsin mutations in Drosophila. Neuron 14 571-579. (doi:10.1016/0896-6273(95)90313-5)
Laffray S, Bouali-Benazzouz R, Papon MA, Favereaux A, Jiang Y, Holm T, Spriet C, Desbarats P, Fossat P, Le Feuvre Y, et al. 2012 Impairment of GABAB receptor dimer by endogenous 14-3-3zeta in chronic pain conditions. EMBO Journal 31 3239-3251. (doi:10.1038/ emboj.2012.161)

Lambert NA 2010 GPCR dimers fall apart. Science Signaling 3 pe12.

Latif R, Graves P \& Davies TF 2001 Oligomerization of the human thyrotropin receptor: fluorescent protein-tagged hTSHR reveals posttranslational complexes. Journal of Biological Chemistry 276 4521745224. (doi:10.1074/jbc.M103727200)

Law CJ, Maloney PC \& Wang DN 2008 Ins and outs of major facilitator superfamily antiporters. Annual Review of Microbiology 62 289-305. (doi:10.1146/annurev.micro.61.080706.093329)

Levoye A, Dam J, Ayoub MA, Guillaume JL, Couturier C, Delagrange P \& Jockers R 2006a The orphan GPR50 receptor specifically inhibits MT1 melatonin receptor function through heterodimerization. EMBO Journal 25 3012-3023.

Levoye A, Dam J, Ayoub MA, Guillaume JL \& Jockers R 2006b Do orphan G-protein-coupled receptors have ligand-independent functions? New insights from receptor heterodimers. EMBO Reports 7 1094-1098.

Li X \& Ma S 2013 Recent developments in the discovery of novel antipsychotic agents modualating dopamine and serotonin receptors. Current Drug Targets 14 899-918. (doi:10.2174/1389450111 3149990007)

Li X, Staszewski L, Xu H, Durick K, Zoller M \& Adler E 2002 Human receptors for sweet and umami taste. PNAS 99 4692-4696. (doi:10.1073/pnas.072090199)

Libri DV, Kleinau G, Vezzoli V, Busnelli M, Guizzardi F, Sinisi AA, Pincelli AI, Mancini A, Russo G, Beck-Peccoz P, et al. 2014 Germline prokineticin receptor 2 (PROKR2) variants associated with central hypogonadism cause differental modulation of distinct intracellular pathways. Journal of Clinical Endocrinology \& Metabolism 99 E458E463.

Limbird LE 2004 The receptor concept: a continuing evolution. Molecular Interventions 4 326-336. (doi:10.1124/mi.4.6.6)

Lodowski DT, Angel TE \& Palczewski K 2009 Comparative analysis of GPCR crystal structures. Photochemistry and Photobiology 85 425-430. (doi:10.1111/j.1751-1097.2008.00516.x)

Lohse MJ 2010 Dimerization in GPCR mobility and signaling. Current Opinion in Pharmacology 10 53-58. (doi:10.1016/j.coph.2009.10.007)

Lohse MJ, Nuber S \& Hoffmann C 2012 Fluorescence/bioluminescence resonance energy transfer techniques to study G-protein-coupled receptor activation and signaling. Pharmacological Reviews 64299 336. (doi:10.1124/pr.110.004309)

Magalhaes AC, Holmes KD, Dale LB, Comps-Agrar L, Lee D, Yadav PN, Drysdale L, Poulter MO, Roth BL, Pin JP, et al. 2010 CRF receptor 1 regulates anxiety behavior via sensitization of 5-HT2 receptor signaling. Nature Neuroscience 13 622-629. (doi:10.1038/nn.2529)

Maldonado-Perez D, Evans J, Denison F, Millar RP \& Jabbour HN 2007 Potential roles of the prokineticins in reproduction. Trends Endocrinol Metab 18 66-72. (doi:10.1016/j.tem.2006.12.002)

Malik AI, Zai CC, Abu Z, Nowrouzi B \& Beitchman JH 2012 The role of oxytocin and oxytocin receptor gene variants in childhood-onset aggression. Genes, Brain and Behavior 11 545-551. (doi:10.1111/j.1601-183X.2012.00776.x)

Mancia F, Assur Z, Herman AG, Siegel R \& Hendrickson WA 2008 Ligand sensitivity in dimeric associations of the serotonin 5HT2c receptor. EMBO Reports 9 363-369. (doi:10.1038/embor.2008.27)

Mandrika I, Petrovska R \& Wikberg J 2005 Melanocortin receptors form constitutive homo- and heterodimers. Biochemical and Biophysical Research Communications 326 349-354. (doi:10.1016/j. bbrc.2004.11.036)

Marsango S, Bonaccorsi di Patti MC, Barra D \& Miele R 2011 Evidence that prokineticin receptor 2 exists as a dimer in vivo. Cellular and Molecular Life Sciences 68 2919-2929.

Published by Bioscientifica Ltd. 
Mason JS, Bortolato A, Congreve M \& Marshall FH 2012 New insights from structural biology into the druggability of $\mathrm{G}$ protein-coupled receptors. Trends in Pharmacological Sciences 33 249-260. (doi:10.1016/j.tips.2012.02.005)

Matsumoto S, Yamazaki C, Masumoto KH, Nagano M, Naito M, Soga T, Hiyama H, Matsumoto M, Takasaki J, Kamohara M, et al. 2006 Abnormal development of the olfactory bulb and reproductive system in mice lacking prokineticin receptor PKR2. PNAS 1034140 4145. (doi:10.1073/pnas.0508881103)

Maurice P, Guillaume JL, Benleulmi-Chaachoua A, Daulat AM, Kamal M \& Jockers R 2011a GPCR-interacting proteins, major players of GPCR function. Advances in Pharmacology 62 349-380.

Maurice P, Kamal M \& Jockers R 2011b Asymmetry of GPCR oligomers supports their functional relevance. Trends in Pharmacological Sciences 32 514-520.

Mazurkiewicz JE, Herrick-Davis K, Barroso M, Ulloa-Aguirre A, LindauShepard B, Thomas RM \& Dias JA 2015 Single-molecule analyses of fully functional fluorescent protein-tagged follitropin receptor reveal homodimerization and specific heterodimerization with lutropin receptor. Biology of Reproduction 92 100. (doi:10.1095/ biolreprod.114.125781)

McLatchie LM, Fraser NJ, Main MJ, Wise A, Brown J, Thompson N, Solari R, Lee MG \& Foord SM 1998 RAMPs regulate the transport and ligand specificity of the calcitonin-receptor-like receptor. Nature 393 333-339. (doi:10.1038/30666)

McMillin SM, Heusel M, Liu T, Costanzi S \& Wess J 2011 Structural basis of M3 muscarinic receptor dimer/oligomer formation. Journal of Biological Chemistry 286 28584-28598. (doi:10.1074/jbc. M111.259788)

Metherell LA, Chapple JP, Cooray S, David A, Becker C, Ruschendorf F, Naville D, Begeot M, Khoo B, Nurnberg P, et al. 2005 Mutations in MRAP, encoding a new interacting partner of the ACTH receptor, cause familial glucocorticoid deficiency type 2. Nature Genetics 37 166-170.

Mohr K, Schmitz J, Schrage R, Trankle C \& Holzgrabe U 2013 Molecular alliance-from orthosteric and allosteric ligands to dualsteric/bitopic agonists at g protein coupled receptors. Angewandte Chemie International Edition in English 52 508-516. (doi:10.1002/ anie.201205315)

Muller A, Kleinau G, Piechowski CL, Muller TD, Finan B, Pratzka J, Gruters A, Krude H, Tschop M \& Biebermann H 2013a G-protein coupled receptor 83 (GPR83) signaling determined by constitutive and zinc(II)-induced activity. PLOS ONE 8 e53347.

Muller TD, Muller A, Yi CX, Habegger KM, Meyer CW, Gaylinn BD, Finan B, Heppner K, Trivedi C, Bielohuby M, et al. 2013b The orphan receptor Gpr83 regulates systemic energy metabolism via ghrelin-dependent and ghrelin-independent mechanisms. Nature Communications 41968.

Murat B, Devost D, Andres M, Mion J, Boulay V, Corbani M, Zingg HH \& Guillon G 2012 V1b and CRHR1 receptor heterodimerization mediates synergistic biological actions of vasopressin and CRH. Molecular Endocrinology 26 502-520. (doi:10.1210/me.2011-1202)

Navarro G, Carriba P, Gandia J, Ciruela F, Casado V, Cortes A, Mallol J, Canela EI, Lluis C \& Franco R 2008 Detection of heteromers formed by cannabinoid CB1, dopamine D2, and adenosine A2A G-proteincoupled receptors by combining bimolecular fluorescence complementation and bioluminescence energy transfer. Scientific World Journal 8 1088-1097. (doi:10.1100/tsw.2008.136)

Negri L, Lattanzi R, Giannini E \& Melchiorri P 2007 Bv8/Prokineticin proteins and their receptors. Life Sciences $\mathbf{8 1} 1103-1116$. (doi:10.1016/j.lfs.2007.08.011)

Ng HK \& Chow BK 2015 Oligomerization of family B GPCRs: exploration in inter-family oligomer formation. Frontiers in Endocrinology 610.

Ng KL, Li JD, Cheng MY, Leslie FM, Lee AG \& Zhou QY 2005 Dependence of olfactory bulb neurogenesis on prokineticin 2 signaling. Science 308 1923-1927. (doi:10.1126/science.1112103)
Ng SY, Lee LT \& Chow BK 2012 Receptor oligomerization: from early evidence to current understanding in class B GPCRs. Frontiers in Endocrinology 3175.

Nijmeijer S, Leurs R, Smit MJ \& Vischer HF 2010 The Epstein-Barr virusencoded $\mathrm{G}$ protein-coupled receptor BILF1 hetero-oligomerizes with human CXCR4, scavenges Galphai proteins, and constitutively impairs CXCR4 functioning. Journal of Biological Chemistry 285 29632-29641. (doi:10.1074/jbc.M110.115618)

Nygaard R, Frimurer TM, Holst B, Rosenkilde MM \& Schwartz TW 2009 Ligand binding and micro-switches in 7TM receptor structures. Trends in Pharmacological Sciences 30 249-259. (doi:10.1016/j.tips.2009.02.006)

O’Hayre M, Vazquez-Prado J, Kufareva I, Stawiski EW, Handel TM, Seshagiri S \& Gutkind JS 2013 The emerging mutational landscape of $\mathrm{G}$ proteins and G-protein-coupled receptors in cancer. Nature Reviews Cancer 13 412-424. (doi:10.1038/nrc3521)

Oldham WM \& Hamm HE 2008 Heterotrimeric G protein activation by G-protein-coupled receptors. Nature Reviews Molecular Cell Biology 9 60-71. (doi:10.1038/nrm2299)

Osuga Y, Hayashi M, Kudo M, Conti M, Kobilka B \& Hsueh AJ 1997 Co-expression of defective luteinizing hormone receptor fragments partially reconstitutes ligand-induced signal generation. Journal of Biological Chemistry 272 25006-25012.

Oswal A \& Yeo GS 2007 The leptin melanocortin pathway and the control of body weight: lessons from human and murine genetics. Obesity Reviews 8 293-306. (doi:10.1111/j.1467-789x.2007.00378.x)

Overton MC \& Blumer KJ 2000 G-protein-coupled receptors function as oligomers in vivo. Current Biology 10 341-344. (doi:10.1016/S09609822(00)00386-9)

Park S, Jiang H, Zhang H \& Smith RG 2012 Modification of ghrelin receptor signaling by somatostatin receptor-5 regulates insulin release. PNAS 109 19003-19008. (doi:10.1073/pnas.1209590109)

Pei L, Li S, Wang M, Diwan M, Anisman H, Fletcher PJ, Nobrega JN \& Liu F 2010 Uncoupling the dopamine D1-D2 receptor complex exerts antidepressant-like effects. Nature Medicine 16 1393-1395. (doi:10.1038/nm.2263)

Pellissier LP, Barthet G, Gaven F, Cassier E, Trinquet E, Pin JP, Marin P, Dumuis A, Bockaert J, Baneres JL, et al. $2011 \mathrm{G}$ protein activation by serotonin type 4 receptor dimers: evidence that turning on two protomers is more efficient. Journal of Biological Chemistry $2869985-$ 9997. (doi:10.1074/jbc.M110.201939)

Perreault ML, Hasbi A, O'Dowd BF \& George SR 2014 Heteromeric dopamine receptor signaling complexes: emerging neurobiology and disease relevance. Neuropsychopharmacology 39 156-168. (doi:10.1038/npp.2013.148)

Persani L, Calebiro D \& Bonomi M 2007 Technology insight: modern methods to monitor protein-protein interactions reveal functional TSH receptor oligomerization. Nature Clinical Practice Endocrinology \& Metabolism 3 180-190.

Pfeiffer M, Koch T, Schroder H, Laugsch M, Hollt V \& Schulz S 2002 Heterodimerization of somatostatin and opioid receptors crossmodulates phosphorylation, internalization, and desensitization. Journal of Biological Chemistry 277 19762-19772. (doi:10.1074/jbc.M110373200)

Piechowski CL, Rediger A, Lagemann C, Muhlhaus J, Muller A, Pratzka J, Tarnow P, Gruters A, Krude H, Kleinau G, et al. 2013 Inhibition of melanocortin-4 receptor dimerization by substitutions in intracellular loop 2. Journal of Molecular Endocrinology 51 109-118. (doi:10.1530/JME-13-0061)

Pin JP, Neubig R, Bouvier M, Devi L, Filizola M, Javitch JA, Lohse MJ, Milligan G, Palczewski K, Parmentier M, et al. 2007 International union of basic and clinical pharmacology. LXVII. Recommendations for the recognition and nomenclature of $G$ protein-coupled receptor heteromultimers. Pharmacological Reviews 59 5-13. (doi:10.1124/ pr.59.1.5)

Piscitelli CL, Kean J, de Graaf C \& Deupi X 2015 A Molecular pharmacologist's guide to $\mathrm{G}$ protein-coupled receptor crystallography. Molecular Pharmacology 88 536-551. (doi:10.1124/mol.115.099663)

Published by Bioscientifica Ltd. 
Prinster SC, Hague C \& Hall RA 2005 Heterodimerization of g proteincoupled receptors: specificity and functional significance. Pharmacological Reviews 57 289-298. (doi:10.1124/pr.57.3.1)

Raivio T, Avbelj M, McCabe MJ, Romero CJ, Dwyer AA, Tommiska J, Sykiotis GP, Gregory LC, Diaczok D, Tziaferi V, et al. 2012 Genetic overlap in Kallmann syndrome, combined pituitary hormone deficiency, and septo-optic dysplasia. Journal of Clinical Endocrinology \& Metabolism 97 E694-E699.

Ramsay D, Kellett E, McVey M, Rees S \& Milligan G 2002 Homo- and hetero-oligomeric interactions between G-protein-coupled receptors in living cells monitored by two variants of bioluminescence resonance energy transfer (BRET): hetero-oligomers between receptor subtypes form more efficiently than between less closely related sequences. Biochemical Journal 365 429-440. (doi:10.1042/ bj20020251)

Rashid AJ, So CH, Kong MM, Furtak T, El-Ghundi M, Cheng R, O'Dowd BF \& George SR 2007 D1-D2 dopamine receptor heterooligomers with unique pharmacology are coupled to rapid activation of Gq/11 in the striatum. PNAS $\mathbf{1 0 4} 654-659$. (doi:10.1073/pnas.0604049104)

Raymond JR 1995 Multiple mechanisms of receptor-G protein signaling specificity. American Journal of Physiology 269 F141-F158.

Rediger A, Tarnow P, Bickenbach A, Schaefer M, Krude H, Gruters A \& Biebermann H 2009 Heterodimerization of hypothalamic G-proteincoupled receptors involved in weight regulation. Obesity Facts 2 80-86. (doi:10.1159/000209862)

Rediger A, Piechowski CL, Yi CX, Tarnow P, Strotmann R, Gruters A, Krude H, Schoneberg T, Tschop MH, Kleinau G, et al. 2011 Mutually opposite signal modulation by hypothalamic heterodimerization of ghrelin and melanocortin-3 receptors. Journal of Biological Chemistry 286 39623-39631. (doi:10.1074/jbc.M111.287607)

Rediger A, Piechowski CL, Habegger K, Gruters A, Krude H, Tschop MH, Kleinau G \& Biebermann H 2012 MC4R Dimerization in the paraventricular nucleus and GHSR/MC3R heterodimerization in the arcuate nucleus: is there relevance for body weight regulation. Neuroendocrinology 95 277-288. (doi:10.1159/000334903)

Regard JB, Sato IT \& Coughlin SR 2008 Anatomical profiling of G protein-coupled receptor expression. Cell 135 561-571. (doi:10.1016/j.cell.2008.08.040)

Reynaud R, Jayakody SA, Monnier C, Saveanu A, Bouligand J, Guedj AM, Simonin G, Lecomte P, Barlier A, Rondard P, et al. 2012 PROKR2 variants in multiple hypopituitarism with pituitary stalk interruption. Journal of Clinical Endocrinology \& Metabolism 97 E1068-E1073.

Rios C, Gomes I \& Devi LA 2006 mu opioid and CB1 cannabinoid receptor interactions: reciprocal inhibition of receptor signaling and neuritogenesis. British Journal of Pharmacology 148 387-395. (doi:10.1038/sj.bjp.0706757)

Ritter SL \& Hall RA 2009 Fine-tuning of GPCR activity by receptorinteracting proteins. Nature Reviews Molecular Cell Biology 10 819830. (doi:10.1038/nrm2803)

Rivero-Muller A, Chou YY, Ji I, Lajic S, Hanyaloglu AC, Jonas K, Rahman N, Ji TH \& Huhtaniemi I 2010 Rescue of defective G protein-coupled receptor function in vivo by intermolecular cooperation. PNAS 107 2319-2324. (doi:10.1073/pnas.0906695106)

Romero-Fernandez W, Borroto-Escuela DO, Agnati LF \& Fuxe K 2013 Evidence for the existence of dopamine d2-oxytocin receptor heteromers in the ventral and dorsal striatum with facilitatory receptor-receptor interactions. Molecular Psychiatry 18 849-850. (doi:10.1038/mp.2012.103)

Rosenbaum DM, Rasmussen SG \& Kobilka BK 2009 The structure and function of G-protein-coupled receptors. Nature 459 356-363. (doi:10.1038/nature08144)

Rozenfeld R \& Devi LA 2011 Exploring a role for heteromerization in GPCR signalling specificity. Biochemical Journal 433 11-18. (doi:10.1042/BJ20100458)
Sakai T, Aoyama M, Kusakabe T, Tsuda M \& Satake H 2008 Functions of a GnRH receptor heterodimer of the ascidian, Ciona intestinalis. Acta Biologica Hungarica 59 (Supplement) 241-243. (doi:10.1556/ ABiol.59.2008.Suppl.34)

Sakai T, Aoyama M, Kawada T, Kusakabe T, Tsuda M \& Satake H 2012 Evidence for differential regulation of $\mathrm{GnRH}$ signaling via heterodimerization among GnRH receptor paralogs in the protochordate, Ciona intestinalis. Endocrinology 153 1841-1849. (doi:10.1210/en.2011-1668)

Satake H, Matsubara S, Aoyama M, Kawada T \& Sakai T 2013 GPCR heterodimerization in the reproductive system: functional regulation and implication for biodiversity. Frontiers in Endocrinology 4100.

Sbai O, Monnier C, Dode C, Pin JP, Hardelin JP \& Rondard P 2014 Biased signaling through G-protein-coupled PROKR2 receptors harboring missense mutations. FASEB Journal 28 3734-3744. (doi:10.1096/fj.13-243402)

Scheerer P, Park JH, Hildebrand PW, Kim YJ, Krauss N, Choe HW, Hofmann KP \& Ernst OP 2008 Crystal structure of opsin in its G-protein-interacting conformation. Nature 455 497-502. (doi:10.1038/nature07330)

Scheerer P, Heck M, Goede A, Park JH, Choe HW, Ernst OP, Hofmann KP \& Hildebrand PW 2009 Structural and kinetic modeling of an activating helix switch in the rhodopsin-transducin interface. PNAS 106 10660-10665. (doi:10.1073/pnas.0900072106)

Schellekens H, van Oeffelen WE, Dinan TG \& Cryan JF 2013 Promiscuous dimerization of the growth hormone secretagogue receptor (GHS-R1a) attenuates ghrelin-mediated signaling. Journal of Biological Chemistry 288 181-191. (doi:10.1074/jbc. M112.382473)

Schelshorn D, Joly F, Mutel S, Hampe C, Breton B, Mutel V \& Lutjens R 2012 Lateral allosterism in the glucagon receptor family: glucagonlike peptide 1 induces G-protein-coupled receptor heteromer formation. Molecular Pharmacology 81 309-318. (doi:10.1124/ mol.111.074757)

Schertler GF 2008 Signal transduction: the rhodopsin story continued. Nature 453 292-293. (doi:10.1038/453292a)

Schlyer S \& Horuk R 2006 I want a new drug: G-protein-coupled receptors in drug development. Drug Discovery Today 11 481-493. (doi:10.1016/j.drudis.2006.04.008)

Schoneberg T, Schulz A, Biebermann H, Hermsdorf T, Rompler H \& Sangkuhl K 2004 Mutant G-protein-coupled receptors as a cause of human diseases. Pharmacology \& Therapeutics 104 173-206.

Schwartz TW, Frimurer TM, Holst B, Rosenkilde MM \& Elling CE 2006 Molecular mechanism of 7TM receptor activation - a global toggle switch model. Annual Review of Pharmacology and Toxicology 46 481-519. (doi:10.1146/annurev.pharmtox.46.120604.141218)

Seeman P, Weinshenker D, Quirion R, Srivastava LK, Bhardwaj SK, Grandy DK, Premont RT, Sotnikova TD, Boksa P, El-Ghundi M, et al. 2005 Dopamine supersensitivity correlates with D2High states, implying many paths to psychosis. PNAS 102 3513-3518. (doi:10.1073/pnas.0409766102)

Seeman P, Ko F, Jack E, Greenstein R \& Dean B 2007 Consistent with dopamine supersensitivity, RGS9 expression is diminished in the amphetamine-treated animal model of schizophrenia and in postmortem schizophrenia brain. Synapse 61 303-309.

Seifert R \& Wenzel-Seifert K 2002 Constitutive activity of G-proteincoupled receptors: cause of disease and common property of wildtype receptors. Naunyn-Schmiedebergs Archives of Pharmacology 366 381-416. (doi:10.1007/s00210-002-0588-0)

Shoichet BK \& Kobilka BK 2012 Structure-based drug screening for G-protein-coupled receptors. Trends in Pharmacological Sciences 33 268-272. (doi:10.1016/j.tips.2012.03.007)

Shonberg J, Scammells PJ \& Capuano B 2011 Design strategies for bivalent ligands targeting GPCRs. ChemMedChem 6 963-974. (doi:10.1002/cmdc.201100101) 
Skieterska K, Duchou J, Lintermans B \& Van Craenenbroeck K 2013 Detection of $\mathrm{G}$ protein-coupled receptor (GPCR) dimerization by coimmunoprecipitation. Methods in Cell Biology 117 323-340. (doi:10.1016/B978-0-12-408143-7.00017-7)

Smith NJ \& Milligan G 2010 Allostery at G protein-coupled receptor homo- and heteromers: uncharted pharmacological landscapes. Pharmacological Reviews 62 701-725. (doi:10.1124/pr.110.002667)

Smit MJ, Vischer HF, Bakker RA, Jongejan A, Timmerman H, Pardo L \& Leurs R 2007 Pharmacogenomic and structural analysis of constitutive g protein-coupled receptor activity. Annual Review of Pharmacology and Toxicology 47 53-87. (doi:10.1146/annurev. pharmtox.47.120505.105126)

Smits G, Olatunbosun O, Delbaere A, Pierson R, Vassart G \& Costagliola S 2003 Ovarian hyperstimulation syndrome due to a mutation in the follicle-stimulating hormone receptor. New England Journal of Medicine 349 760-766. (doi:10.1056/NEJMoa030064)

Song GJ \& Hinkle PM 2005 Regulated dimerization of the thyrotropinreleasing hormone receptor affects receptor trafficking but not signaling. Molecular Endocrinology 19 2859-2870. (doi:10.1210/me.2005-0133)

Song GJ, Jones BW \& Hinkle PM 2007 Dimerization of the thyrotropinreleasing hormone receptor potentiates hormone-dependent receptor phosphorylation. PNAS 104 18303-18308. (doi:10.1073/ pnas.0702857104)

Sposini S, Caltabiano G, Hanyaloglu AC \& Miele R 2015 Identification of transmembrane domains that regulate spatial arrangements and activity of prokineticin receptor 2 dimers. Molecular and Cellular Endocrinology 399 362-372. (doi:10.1016/j.mce.2014.10.024)

Sun Y, Lu X \& Gershengorn MC 2003 Thyrotropin-releasing hormone receptors - similarities and differences. Journal of Molecular Endocrinology 30 87-97. (doi:10.1677/jme.0.0300087)

Surgand JS, Rodrigo J, Kellenberger E \& Rognan D 2006 A chemogenomic analysis of the transmembrane binding cavity of human G-protein-coupled receptors. Proteins 62 509-538.

Svendsen AM, Vrecl M, Ellis TM, Heding A, Kristensen JB, Wade JD, Bathgate RA, De Meyts P \& Nohr J 2008 Cooperative binding of insulin-like Peptide 3 to a dimeric relaxin family peptide receptor 2 . Endocrinology 149 1113-1120. (doi:10.1210/en.2007-0412)

Svendsen AM, Vrecl M, Knudsen L, Heding A, Wade JD, Bathgate RA, De Meyts P \& Nohr J 2009 Dimerization and negative cooperativity in the relaxin family peptide receptors. Annals of the New York Academy of Sciences 1160 54-59. (doi:10.1111/j.1749-6632.2009.03835.x)

Tadagaki K, Jockers R \& Kamal M 2011 History and biological significance of GPCR heteromerization in the neuroendocrine system. Neuroendocrinology 95 223-231. (doi:10.1159/000330000)

Tadagaki K, Jockers R \& Kamal M 2012a History and biological significance of GPCR heteromerization in the neuroendocrine system. Neuroendocrinology 95 223-231.

Tadagaki K, Tudor D, Gbahou F, Tschische P, Waldhoer M, Bomsel M, Jockers R \& Kamal M 2012b Human cytomegalovirus-encoded UL33 and UL78 heteromerize with host CCR5 and CXCR4 impairing their HIV coreceptor activity. Blood 119 4908-4918.

Tao YX 2006 Inactivating mutations of G protein-coupled receptors and diseases: structure-function insights and therapeutic implications. Pharmacology \& Therapeutics 111 949-973.

Tao YX 2010 Mutations in the melanocortin-3 receptor (MC3R) gene: Impact on human obesity or adiposity. Current Opinion in Investigational Drugs 11 1092-1096.

Tao YX, Johnson NB \& Segaloff DL 2004 Constitutive and agonistdependent self-association of the cell surface human lutropin receptor. Journal of Biological Chemistry 279 5904-5914. (doi:10.1074/ jbc.M311162200)

Tarnow P, Rediger A, Brumm H, Ambrugger P, Rettenbacher E, Widhalm K, Hinney A, Kleinau G, Schaefer M, Hebebrand J, et al. 2008 A heterozygous mutation in the third transmembrane domain causes a dominant-negative effect on signalling capability of the MC4R. Obesity Facts 1 155-162. (doi:10.1159/000138251)
Tate CG \& Schertler GF 2009 Engineering G protein-coupled receptors to facilitate their structure determination. Current Opinion in Structural Biology 19 386-395. (doi:10.1016/j.sbi.2009.07.004)

Teichmann A, Rutz C, Kreuchwig A, Krause G, Wiesner B \& Schulein R 2012 The pseudo signal peptide of the corticotropin-releasing factor receptor type $2 \mathrm{~A}$ prevents receptor oligomerization. Journal of Biological Chemistry 287 27265-27274. (doi:10.1074/jbc. M112.360594)

Teichmann A, Gibert A, Lampe A, Grzesik P, Rutz C, Furkert J, Schmoranzer J, Krause G, Wiesner B \& Schulein R 2014 The specific monomer/dimer equilibrium of the corticotropin-releasing factor receptor type 1 is established in the endoplasmic reticulum. Journal of Biological Chemistry 289 24250-24262. (doi:10.1074/jbc. M114.553644)

Teitler M \& Klein MT 2012 A new approach for studying GPCR dimers: drug-induced inactivation and reactivation to reveal GPCR dimer function in vitro, in primary culture, and in vivo. Pharmacology \& Therapeutics 133 205-217.

Terrillon S, Durroux T, Mouillac B, Breit A, Ayoub MA, Taulan M, Jockers R, Barberis C \& Bouvier M 2003 Oxytocin and vasopressin V1a and V2 receptors form constitutive homo- and heterodimers during biosynthesis. Molecular Endocrinology 17 677-691. (doi:10.1210/me.2002-0222)

Terrillon S, Barberis C \& Bouvier M 2004 Heterodimerization of V1a and $\mathrm{V} 2$ vasopressin receptors determines the interaction with betaarrestin and their trafficking patterns. PNAS 101 1548-1553. (doi:10.1073/pnas.0305322101)

Themmen APN \& Huhtaniemi IT 2000 Mutations of gonadotropins and gonadotropin receptors: elucidating the physiology and pathophysiology of pituitary-gonadal function. Endocrine Reviews $\mathbf{2 1}$ 551-583. (doi:10.1210/edrv.21.5.0409)

Tripathi A, Vana PG, Chavan TS, Brueggemann LI, Byron KL, Tarasova NI, Volkman BF, Gaponenko V \& Majetschak M 2015 Heteromerization of chemokine (C-X-C motif) receptor 4 with alpha1A/B-adrenergic receptors controls alpha1-adrenergic receptor function. PNAS 112 E1659-E1668.

Troppmann B, Kleinau G, Krause G \& Gromoll J 2013 Structural and functional plasticity of the luteinizing hormone/ choriogonadotrophin receptor. Human Reproduction Update $19583-$ 602. (doi:10.1093/humupd/dmt023)

Tschische P, Tadagaki K, Kamal M, Jockers R \& Waldhoer M 2011 Heteromerization of human cytomegalovirus encoded chemokine receptors. Biochemical Pharmacology 82 610-619. (doi:10.1016/j. bcp.2011.06.009)

Tyndall JD \& Sandilya R 2005 GPCR agonists and antagonists in the clinic. Medicinal Chemistry 1 405-421. (doi:10.2174/ 1573406054368675)

Uberti MA, Hague C, Oller H, Minneman KP \& Hall RA 2005 Heterodimerization with beta2-adrenergic receptors promotes surface expression and functional activity of alpha1D-adrenergic receptors. Journal of Pharmacology and Experimental Therapeutics 313 16-23.

Uddin MS, Kim H, Deyo A, Naider F \& Becker JM 2012 Identification of residues involved in homodimer formation located within a betastrand region of the N-terminus of a Yeast G protein-coupled receptor. Journal of Receptors and Signal Transduction Research 32 65-75. (doi:10.3109/10799893.2011.647352)

Urizar E, Montanelli L, Loy T, Bonomi M, Swillens S, Gales C, Bouvier M, Smits G, Vassart G \& Costagliola S 2005 Glycoprotein hormone receptors: link between receptor homodimerization and negative cooperativity. EMBO Journal 24 1954-1964. (doi:10.1038/ sj.emboj.7600686)

van Unen J, Woolard J, Rinken A, Hoffmann C, Hill SJ, Goedhart J, Bruchas MR, Bouvier M \& Adjobo-Hermans MJ 2015 A perspective on studying G-protein-coupled receptor signaling with resonance energy transfer biosensors in living organisms. Molecular Pharmacology 88 589-595. (doi:10.1124/mol.115.098897) 
Vassart G \& Costagliola S 2011 G protein-coupled receptors: mutations and endocrine diseases. Nature Reviews Endocrinology 7 362-372. (doi:10.1038/nrendo.2011.20)

Vassart G \& Kleinau G 2014 TSH receptor mutations and diseases. In Endotext. Eds LJ De Groot, P Beck-Peccoz, G Chrousos, K Dungan, A Grossman, JM Hershman, C Koch, R McLachlan, M New, R Rebar, et al. South Dartmouth, MA, USA: MDText.com, Inc.

Veldhuis NA, Poole DP, Grace M, McIntyre P \& Bunnett NW 2015 The $\mathrm{G}$ protein-coupled receptor-transient receptor potential channel axis: molecular insights for targeting disorders of sensation and inflammation. Pharmacological Reviews 67 36-73.

Vidi PA \& Watts VJ 2009 Fluorescent and bioluminescent proteinfragment complementation assays in the study of $\mathrm{G}$ protein-coupled receptor oligomerization and signaling. Molecular Pharmacology $\mathbf{7 5}$ 733-739. (doi:10.1124/mol.108.053819)

Viero C, Shibuya I, Kitamura N, Verkhratsky A, Fujihara H, Katoh A, Ueta Y, Zingg HH, Chvatal A, Sykova E, et al. 2010 REVIEW: oxytocin: crossing the bridge between basic science and pharmacotherapy. CNS Neuroscience \& Therapeutics 16 e138-156.

Vilardaga JP, Nikolaev VO, Lorenz K, Ferrandon S, Zhuang Z \& Lohse M 2008 Conformational cross-talk between alpha2A-adrenergic and mu-opioid receptors controls cell signaling. Nature Chemical Biology 4 126-131. (doi:10.1038/nchembio.64)

Waldhoer M, Fong J, Jones RM, Lunzer MM, Sharma SK, Kostenis E, Portoghese PS \& Whistler JL 2005 A heterodimer-selective agonist shows in vivo relevance of $G$ protein-coupled receptor dimers. PNAS 102 9050-9055. (doi:10.1073/pnas.0501112102)

Walther C \& Ferguson SS 2015 Minireview: role of intracellula scaffolding proteins in the regulation of endocrine $\mathrm{G}$ proteincoupled receptor signaling. Molecular Endocrinology 29 814-830. (doi:10.1210/me.2015-1091)

Wess J 1998 Molecular basis of receptor/G-protein-coupling selectivity. Pharmacology \& Therapeutics 80 231-264.

Whistler JL, Enquist J, Marley A, Fong J, Gladher F, Tsuruda P, Murray SR \& Von Zastrow M 2002 Modulation of postendocytic sorting of G proteincoupled receptors. Science 297 615-620. (doi:10.1126/science.1073308)

White JF, Grodnitzky J, Louis JM, Trinh LB, Shiloach J, Gutierrez J, Northup JK \& Grisshammer R 2007 Dimerization of the class A $\mathrm{G}$ protein-coupled neurotensin receptor NTS1 alters $\mathrm{G}$ protein interaction. PNAS 104 12199-12204. (doi:10.1073/pnas.0705312104)

Whorton MR, Bokoch MP, Rasmussen SG, Huang B, Zare RN, Kobilka B \& Sunahara RK 2007 A monomeric G protein-coupled receptor isolated in a high-density lipoprotein particle efficiently activates its G protein. PNAS 104 7682-7687. (doi:10.1073/pnas.0611448104)

Wichard JD, Ter Laak A, Krause G, Heinrich N, Kuhne R \& Kleinau G 2011 Chemogenomic analysis of G-protein coupled receptors and their ligands deciphers locks and keys governing diverse aspects of signalling. PLOS ONE 6 e16811.

Wilson SJ, McGinley K, Huang AJ \& Smyth EM 2007 Heterodimerization of the alpha and beta isoforms of the human thromboxane receptor enhances isoprostane signaling. Biochemical and Biophysical Research Communications 352 397-403. (doi:10.1016/j.bbrc.2006.11.040)

Wrzal PK, Devost D, Petrin D, Goupil E, Iorio-Morin C, Laporte SA, Zingg HH \& Hebert TE 2012a Allosteric interactions between the oxytocin receptor and the beta2-adrenergic receptor in the modulation of ERK1/2 activation are mediated by heterodimerization. Cell Signaling 24 342-350.

Wrzal PK, Goupil E, Laporte SA, Hebert TE \& Zingg HH $2012 b$ Functional interactions between the oxytocin receptor and the beta2-adrenergic receptor: implications for ERK1/2 activation in human myometrial cells. Cell Signaling 24 333-341.

Wu B, Chien EY, Mol CD, Fenalti G, Liu W, Katritch V, Abagyan R, Brooun A, Wells P, Bi FC, et al. 2010 Structures of the CXCR4 chemokine GPCR with small-molecule and cyclic peptide antagonists. Science 330 1066-1071. (doi:10.1126/science.1194396)

Wu H, Wacker D, Mileni M, Katritch V, Han GW, Vardy E, Liu W, Thompson AA, Huang XP, Carroll FI, et al. 2012 Structure of the human kappa-opioid receptor in complex with JDTic. Nature $\mathbf{4 8 5}$ 327-332. (doi:10.1038/nature10939)

Xie Z, Westmoreland SV \& Miller GM 2008 Modulation of monoamine transporters by common biogenic amines via trace amine-associated receptor 1 and monoamine autoreceptors in human embryonic kidney 293 cells and brain synaptosomes. Journal of Pharmacology and Experimental Therapeutics 325 629-640. (doi:10.1124/ jpet.107.135079)

Yanagawa M, Yamashita T \& Shichida Y 2011 Comparative fluorescence resonance energy transfer analysis of metabotropic glutamate receptors: implications about the dimeric arrangement and rearrangement upon ligand bindings. Journal of Biological Chemistry 286 22971-22981. (doi:10.1074/jbc.M110.206870)

Yekkirala AS 2013 Two to tango: GPCR oligomers and GPCR-TRP channel interactions in nociception. Life Sciences 92 438-445. (doi:10.1016/j.lfs.2012.06.021)

Young SF, Griffante C \& Aguilera G 2007 Dimerization between vasopressin $\mathrm{V} 1 \mathrm{~b}$ and corticotropin releasing hormone type 1 receptors. Cellular and Molecular Neurobiology 27 439-461. (doi:10.1007/s10571-006-9135-8)

Yuan Y, Arnatt CK, El-Hage N, Dever SM, Jacob JC, Selley DE, Hauser KF \& Zhang Y 2013 A bivalent ligand targeting the putative mu opioid receptor and chemokine receptor CCR5 heterodimers: binding affinity versus functional activities. MedChemComm 4 847-851. (doi:10.1039/c3md00080j)

Zhao Q \& Wu BL 2012 Ice breaking in GPCR structural biology. Acta Pharmacologica Sinica 33 324-334. (doi:10.1038/aps.2011.187)

Zhou W, Li JD, Hu WP, Cheng MY \& Zhou QY 2012 Prokineticin 2 is involved in the thermoregulation and energy expenditure. Regulatory Peptides 179 84-90. (doi:10.1016/j.regpep.2012.08.003)

Zhu X \& Wess J 1998 Truncated V2 vasopressin receptors as negative regulators of wild-type V2 receptor function. Biochemistry $\mathbf{3 7}$ 15773-15784. (doi:10.1021/bi981162z)

Zhu CC, Cook LB \& Hinkle PM 2002 Dimerization and phosphorylation of thyrotropin-releasing hormone receptors are modulated by agonist stimulation. Journal of Biological Chemistry 277 28228-28237. (doi:10.1074/jbc.M204221200)

Zoenen M, Urizar E, Swillens S, Vassart G \& Costagliola S 2012 Evidence for activity-regulated hormone-binding cooperativity across glycoprotein hormone receptor homomers. Nature Communications $\mathbf{3}$ 1007. (doi:10.1038/ncomms1991)

Received in final form 25 April 2016

Accepted 4 May 2016

Accepted Preprint published online 5 May 2016 http://jme.endocrinology-journals.org

DOI: 10.1530/JME-16-0049
() 2016 Society for Endocrinology Printed in Great Britain
Published by Bioscientifica Ltd 